\section{Quantitative diamondoid analysis indicates oil cosourcing from a deep petroleum system onshore Niger Delta Basin}

\section{Onoriode Esegbue, D. Martin Jones, Pim F. van Bergen, and Sadat Kolonic}

\section{ABSTRACT}

The Niger Delta Basin is one of the most prolific hydrocarbon provinces in the world, yet the origin of the vast amounts of oil and gas found in the numerous subbasins across the delta remains contested. A total of 180 oil samples from more than 40 oil fields in the Niger Delta were analyzed by gas chromatography (GC) and GC-mass spectrometry, and selected samples were analyzed by GC-tandem mass spectrometry.

The interpreted thermal maturity and source depositional environments of these hydrocarbons show significant variation depending on the components analyzed and allow no clear correlation to a single source rock but rather imply extensive mixed contributions. Diamondoid hydrocarbon parameters were used for the first time on these Paleogene-Neogene reservoired oils to investigate source, thermal maturity, and mixing effects and perform cross correlations of these oils. The diamondoid abundances and distributions support the hypothesis of cosourcing of oil from a thermally cracked, subdelta, type II marine source, which was then mixed with oils of relatively lower maturities in the Paleogene-Neogene reservoirs.

Future geochemical interpretations should treat the Niger Delta oils as potential mixtures of oils of variable maturities from different sources, commonly with the most important source biomarkers depleted because of the extent of thermal cracking.

Copyright (C2020. The American Association of Petroleum Geologists. All rights reserved. Gold Open Access. This paper is published under the terms of the CC-BY license.

Manuscript received September 3, 2016; provisional acceptance December 22, 2016; revised manuscript received December 1, 2017; revised manuscript provisional acceptance January 16, 2018; 2nd revised manuscript received November 26, 2018; 2nd revised manuscript provisional acceptance January 30, 2019; 3rd revised manuscript received May 17, 2019; 3rd revised manuscript provisional acceptance June 21, 2019; 4th revised manuscript received August 21, 2019; final acceptance January 22, 2020.

DOI:10.1306/0122201618217407

\section{AUTHORS}

ONORIODE ESEGBUE School of Civil Engineering and Geosciences, Newcastle University, Newcastle upon Tyne, United Kingdom; present address: The Lyell Centre, Heriot-Watt University, Edinburgh, United Kingdom; o.esegbue@hw.ac.uk

Onoriode Esegbue is a postdoctoral research associate at Herriot Watt University, Edinburgh, characterizing ultra-deep-water black shales. He obtained a B.Sc. in geology (Delta State University, Nigeria), M.Sc. in petroleum geology (University of Ibadan, Nigeria) and petroleum geochemistry (Newcastle University, United Kingdom), and a Ph.D. in petroleum geochemistry (Newcastle University, United Kingdom). He has more than 5 years of experience in oil and gas consultancy, previously working as a geoscientist focusing on petroleum systems analysis.

D. MARTIN JONES School of Civil Engineering and Geosciences, Newcastle University, Newcastle upon Tyne, United Kingdom; martin.jones@ncl.ac.uk

D. Martin Jones is a senior lecturer in organic geochemistry at Newcastle University, United Kingdom. He obtained his B.Sc. in chemistry at Cardiff University and M.Sc. and Ph.D. in organic geochemistry at Newcastle University. His research interests include the development and application of organic geochemical analytical techniques to geological and biogeochemical problems, particularly on the biodegradation of hydrocarbons in surface and subsurface environments.

PIM F. VAN Bergen Shell United Kingdom Ltd., Aberdeen, United Kingdom; pim.vanBergen@shell.com

Pim F. van Bergen is the principal technical expert for production geochemistry in Shell currently working for Shell United Kingdom in Aberdeen, United Kingdom. He obtained his M.Sc. in biology from Utrecht University and a Ph.D. in organic geochemistry at Royal Holloway, University of London. He is involved in the development and application of organic geochemical analytical techniques to production geochemical issues ranging from operations, reservoir surveillance, production 
allocation, and well integrity evaluations to decommissioning and restoration.

Sadat Kolonic Shell Petroleum Development Company of Nigeria Ltd. (SPDC), Port Harcourt, Nigeria; sadat.kolonic@shell.com

Sadat Kolonic is a principal geoscientist (exploration capability) with SPDC in Port Harcourt (Nigeria), overseeing a diverse portfolio of exploration and development projects providing charge risk, fluid property assessment, and reservoir fluid characterization to determine better understanding of lateral and vertical reservoir continuity, hydrocarbon quality, and producibility in a near-field experiment and high-pressure-high-temperature environment. He obtained his diploma in applied geology and a Dr.rer.nat. in organic geochemistry from the University of Bremen (Germany).

\section{ACKNOWLEDGMENTS}

We acknowledge SPDC for providing samples and permission to publish this work and the Nigerian Department of Petroleum Resources for permission to access the samples. The Petroleum Technology Development Fund of Nigeria is gratefully acknowledged for funding Onoriode Esegbue's research studentship. Paul Donohoe, Bernard Bowler, and Philip Green of the School of Civil Engineering and Geosciences, Newcastle University, are thanked for their analytical support during the course of this research. We also thank Erik Tegelaar for useful discussions on diamondoids and Erdem Idiz and Herwig Ganz for sharing their thoughts on the Niger Delta Basin with the authors. Finally, the authors wish to thank previous AAPG Editor Barry J. Katz and reviewers Alexander Chakhmakhchev and Jessica Little for their helpful suggestions, which have improved the paper.

\section{INTRODUCTION}

The Niger Delta Basin is located in the southern part of Nigeria (Figure 1), with a sediment thickness of approximately $2 \mathrm{~km}$ $(\sim 6550 \mathrm{ft})$ at the flank of the basin (Tuttle et al., 1999) and average of $12 \mathrm{~km}$ (average of 39,400 ft) at the basin center (Kulke, 1995). The basin holds approximately $2.3 \%$ of the world's known oil and gas reserves (79.5 billion bbl of oil and $127.2 \mathrm{tcf}$ ), which makes it the twelfth largest oil province in the world (Liu et al., 2008; Sonibare et al., 2008). However, despite more than $60 \mathrm{yr}$ of oil production in the Niger Delta, there are still controversies in defining the petroleum system (Samuel et al., 2009) and especially the source $\operatorname{rock}(\mathrm{s})$ that generated these significant hydrocarbon volumes (Ejedawe et al., 1984; Ekweozor and Daukoru, 1984; Lambert-Aikhionbare and Ibe, 1984; Haack et al., 2000).

Three known stratigraphic units (Figure 2) are present in the Paleogene-Neogene Niger Delta: the Akata, Agbada, and Benin Formations (Haack et al., 2000; Corredor et al., 2005). A strong indication exists of a Cretaceous shale that lies unconformably on the basement with thickness of up to $2 \mathrm{~km}$ ( up to $6550 \mathrm{ft}$ ) in the offshore part of the basin (Figure 2; Bellingham et al., 2014), but its distribution is poorly constrained (Reijers, 2011). The Cretaceous shales have not been drilled in the Niger Delta area primarily because they are too deeply buried beneath the overpressured Akata Formation and the thick overburden above them (Reijers, 2011).

The lack of mature source rock sample availability and the variability in fluid types (oil, gas, and condensates) from the different subbasins in the Niger Delta, even at very close proximity to each other, have made it difficult to ascertain the source of the hydrocarbons in the basin. The main aim of this study was to gain a better understanding of the Niger Delta petroleum systems with a view to predicting the source rocks of the oil in the basin; ultimately, we aimed to predict the likely mixing percentages of high maturity-sourced oil with those generated at lower thermal maturities and how this mixing may change across the regions of the delta.

The saturated and aromatic hydrocarbon fractions of samples were analyzed by gas chromatography (GC) and GC-mass spectrometry (GCMS) to provide detailed compositional information. In particular, the diamondoid hydrocarbons in the oils were quantitatively analyzed by GCMS to better classify the oils and their sources. A Norwegian Petroleum Directorate (NPD) geochemical standard North Sea oil (NSO-1) from the Oseberg field was also analyzed for quality control purposes and to enable comparison of the results from the Niger Delta oils, with those from a thermally mature marine-sourced oil sourced from a single source rock. 


\section{TECTONICS, STRATIGRAPHY, AND DEPOSITIONAL SEQUENCE}

Rifting along the West African margin began in the Late Jurassic and did not cease until the middle Cretaceous (Lehner and De Ruiter, 1977). This rifting led to the formation of the Niger Delta Basin during the breakup of the South American and African plates (Whiteman, 1982). This breakup was mainly controlled by the failed arm of a rift triple junction that formed the Benue trough (Lehner and De Ruiter, 1977) and was associated with the South Atlantic sea opening. This tectonic framework along the West African margin was responsible for the formation of several fracture zones that form notable trenches and ridges in the Atlantic Ocean (Tuttle et al., 1999).

The undercompacted and overpressured Akata Formation is responsible for the formation of complex gravity tectonics in the delta, with the formation of shale diapirs occurring as a result of the overburden of the Agbada Formation on the Akata Formation on the delta slope with continual progradation. Thus, the delta slope became unstable because of the mobile Akata Formation not finding suitable support basinward as the delta prograded (Kulke, 1995).

The complex gravity tectonics in this basin ended with the deposition of the Benin Formation on depobelts in the delta (Evamy et al., 1978). This was marked with the formation of shale diapirs, growth faults, rollover anticlines, antithetic faults, and so forth (Evamy et al., 1978).

The diachronous Akata Formation is composed of thick marine shale across the delta with some turbidites in the deep water and the possibility of localized occurrences of clay and silt (Avbovbo, 1978; Doust and Omatsola, 1990). This formation was believed to have been developed during a lowstand characterized by low oxygen supply and reduced energy conditions (Stacher, 1995). Its thickness has been estimated at approximately $7 \mathrm{~km}(\sim 22,950 \mathrm{ft})$ in the basin center and thins toward the deep offshore (Doust and Omatsola, 1990).

The overlying paralic Agbada Formation was deposited during the Eocene but continued until recently because of the diachronous nature of deposition in the basin (Short and Stauble, 1967). The Agbada Formation has a thickness of up to $3.7 \mathrm{~km}$ (up to $12,150 \mathrm{ft}$ ) in some areas and is typically characterized by fluvial-deltaic depositional signatures (Tuttle

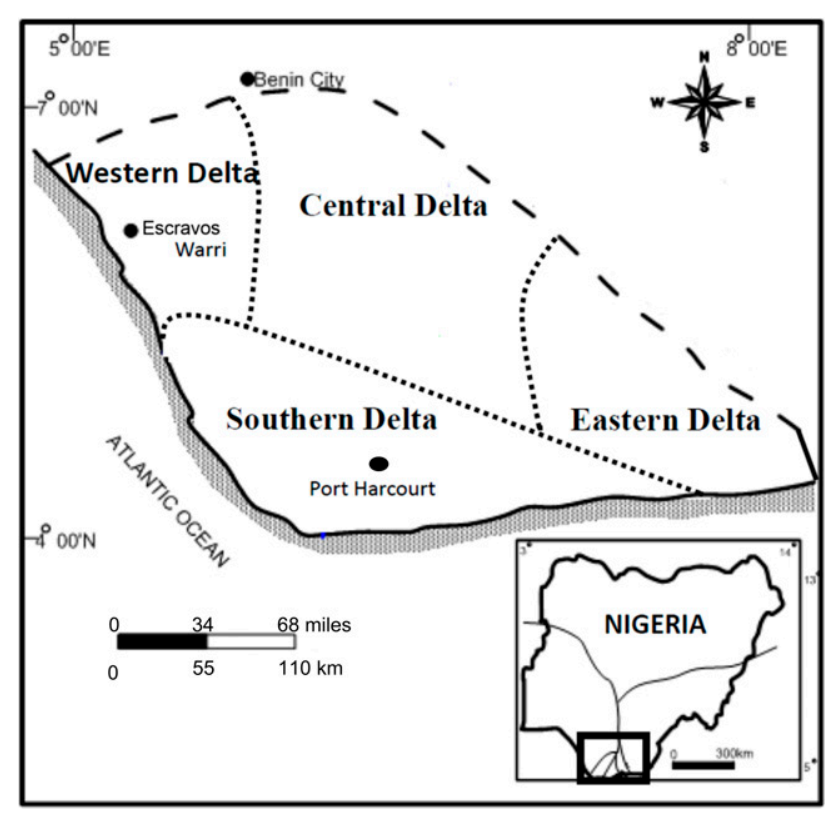

Figure 1. Map of Nigeria showing the location of Niger Delta Basin and the division of the delta into western, central, eastern, and southern deltas.

et al., 1999). The Benin Formation, the youngest formation in the delta, was deposited from the Eocene to Holocene with thicknesses generally averaging approximately $2 \mathrm{~km}$ ( 6550 ft) (Avbovbo, 1978). The sediments were deposited in a predominantly continental environment characterized by braided and meandering river systems (Obaje, 2009).

\section{SOURCE ROCKS}

Various scenarios exist when trying to constrain the source rocks of the Niger Delta Basin, with possibilities ranging from proven to speculative. The major problem in constraining the source rocks of the basin is that the Agbada Formation most commonly encountered during drilling is thermally immature and thick with very low total organic carbon (TOC) content and hydrogen index (HI) values and therefore has a low possibility of having been the only source of the oil reserves in the basin. Many authors have written about the source rocks in the basin (e.g., Short and Stauble, 1967; Evamy et al., 1978; Ekweozor et al., 1979; Ekweozor and Okoye, 1980; Bustin 1988; Doust and Omatsola, 1990; Ekweozor and Daukoru, 1994; Haack et al., 2000; Eneogwe and Ekundayo, 2003; Akinlua et al., 2006; Samuel et al., 


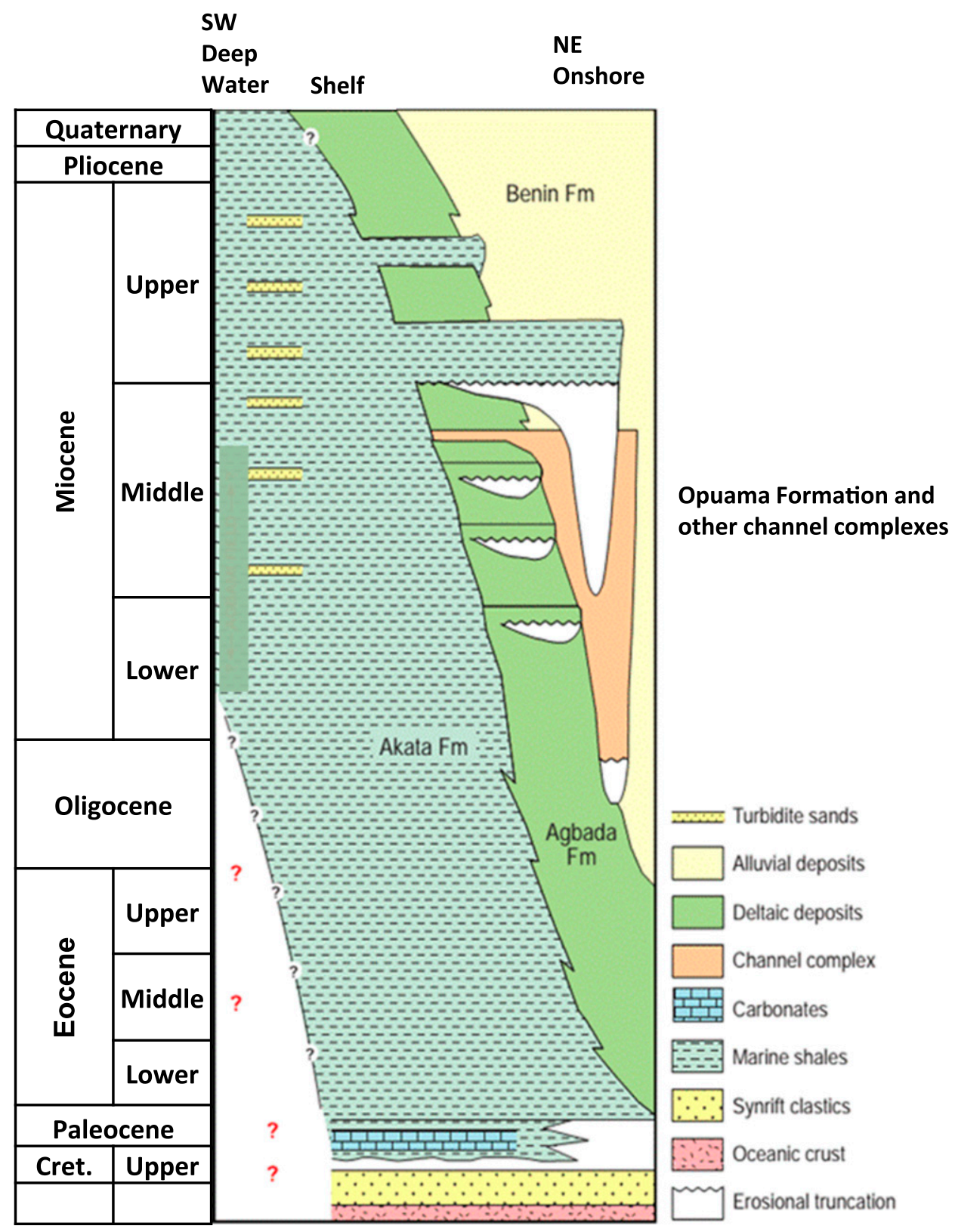

Figure 2. Regional stratigraphy of the Niger Delta Basin showing the three major stratigraphic units present in the delta (Akata, Agbada, and Benin Formations [Fm]). The question marks note the possible occurrence of an unknown Cretaceous (Cret.) formation. The age of this formation varies depending on where you are Deep offshore to onshore (Cretaceous to Oligocene) (Corredor et al., 2005). Reprinted with permission of AAPG.

2009; Lehne and Dieckmann, 2010), with most of them having variable levels of uncertainty because the Paleogene-Neogene reservoired oils correlate poorly with the Paleogene-Neogene source rocks encountered during drilling in the basin (Samuel et al., 2009).

The possible sources of the Niger Delta hydrocarbons, as pointed out by most authors, include one, or a combination, of (1) marine shales of the Agbada Formation, (2) top marine shales of the Akata Formation, (3) inferred Cretaceous marine shale (subdelta?), and/or (4) inferred Lower Cretaceous lacustrine formation (subdelta?).

The transgressive shales of the paralic Agbada Formation have some intervals with high generation potential (Ekweozor and Okoye, 1980; Nwachukwu and Chukwura, 1986). However, these shales are too immature in most parts of the basin to generate hydrocarbons, and their thicknesses are very limited, 
commonly between a few centimeters to tens of centimeters (Evamy et al., 1978; Ekweozor and Okoye, 1980; Stacher, 1995). Bustin (1988) showed that their TOC contents increase with age from 0.9 wt. $\%$ to 2.2 wt. $\%$ and concluded that the shales of the paralic Agbada Formation have low hydrocarbon generation potential with most of the samples having less than 1.2 wt. \% TOC.

A wide range of difference in the reported geochemical results of the thermally immature source rock samples exists. The reported TOC values mostly vary between $0.9 \mathrm{wt}$. \% to $2.2 \mathrm{wt}$. \% (Bustin, 1988), 2.3 wt. \% to 2.5 wt. \% (Ekweozor and Udo, 1988), and 0.21 wt. \% to 4.22 wt. \% (Akinlua and Torto, 2011). However, Doust and Omatsola (1990) point out that the beds with high TOC content are always very thin and commonly insignificant based on their studies on core samples from different wells in the basin. The HI values of the thermally immature shales are also very low (e.g., 50-160 mg $\mathrm{HC} / \mathrm{g}$ TOC) with an average value of $90 \mathrm{mg} \mathrm{HC/g}$ TOC (Bustin, 1988), 38 to $239 \mathrm{mg} \mathrm{HC/g}$ TOC (Akinlua and Torto, 2011). This shows that they have potential to generate gas and some oil (Baskin, 1997). Therefore, it can be concluded that the Agbada Formation, although thick, has generally low TOC and HI values, and source rock samples are generally immature. Thus, the Agbada Formation cannot be the main source of the major petroleum systems in the delta.

The marine shale of the Akata Formation is deeply buried in most parts of the basin and should be in the oil generation window (Stacher, 1995) with sufficient thicknesses (a few meters to $7 \mathrm{~km}$ [a few feet to 22,950 $\mathrm{ft}$ ] thick at the basin center) to have sourced the Paleogene-Neogene reservoired oil in the delta (Stacher, 1995). However, Lambert-Aikhionbare and Ibe (1984) believed that the overpressured and undercompacted nature of this formation would reduce the migration efficiency to approximately $12 \%$, thereby reducing the overall expulsion of generated hydrocarbons from this formation to a minimum.

Some authors argue in favor of multiple contributory sources to the hydrocarbon reserves in the delta, with Evamy et al. (1978) basing their argument on the organic matter type and organic matter contents of both Akata and Agbada Formations, whereas Ekweozor et al. (1979) believe the oil in the eastern delta is derived from the shales of the Agbada Formation, whereas those in the western delta are cosourced from both Akata and Agbada Formations based on $\alpha \beta$-hopane and -oleanane compositions of oils. Cretaceous marine and lacustrine shales beneath the Paleogene-Neogene Niger Delta have also been proposed as a possible mixed contributory source of the reservoired oil in the delta because they are proven in the nearby Dahomey and Anambra basins (Frost, 1997; Haack et al., 2000). This has not been proven in the Niger Delta Basin because Cretaceousaged samples are not available since exploration wells are not drilled deep enough to penetrate them (Reijers, 2011). It is also not proven that migration pathways exist within the Akata shales for hydrocarbons generated in the underlying Cretaceous formations to migrate through (Tuttle et al., 1999). However, Bellingham et al. (2014) show some prestacked and depth-migrated regional seismic sections of 18-s two-way traveltime with severe brittle deformation through the Akata Formation that could serve as a good migration route for the hydrocarbons generated in the Cretaceous formations. A Gulf of Mexico model, in which deeply buried older rocks mainly sourced the oil and gas in the basin, has been invoked by Haack et al. (2000) and was supported by the model developed by Samuel et al. (2007, 2009).

Although a Cretaceous source for the Niger Delta Basin oil is hypothetical and unproven (Frost, 1997; Haack et al., 2000; Samuel et al., 2007, 2009), other coeval basins along the South Atlantic margin have proven Cretaceous source rocks (Figure 3; Table 1).

\section{RESERVOIR ROCKS}

The oil and gas reserves in the Niger Delta Basin are mostly reservoired in the sandstones and sands of the paralic Agbada Formation, with the lithologic characteristics of individual fields dependent on burial depth and depositional environment (Tuttle et al., 1999). Reservoir thicknesses increase where there is stacking of multiple sand facies (Doust and Omatsola, 1990). Although Evamy et al. (1978) indicate that reservoir thicknesses range from 15 to $45 \mathrm{~m}(49.2$ to $147.6 \mathrm{ft}$ ), Edwards and Santogrossi (1990) point out that most reservoirs are up to $100 \mathrm{~m}$ (up to $330 \mathrm{ft}$ ) thick, with porosities of $40 \%$ possible in shallow reservoirs but generally are approximately $15 \%$ at $3-\mathrm{km}$ (9840-ft) sediment thickness and with permeabilities 


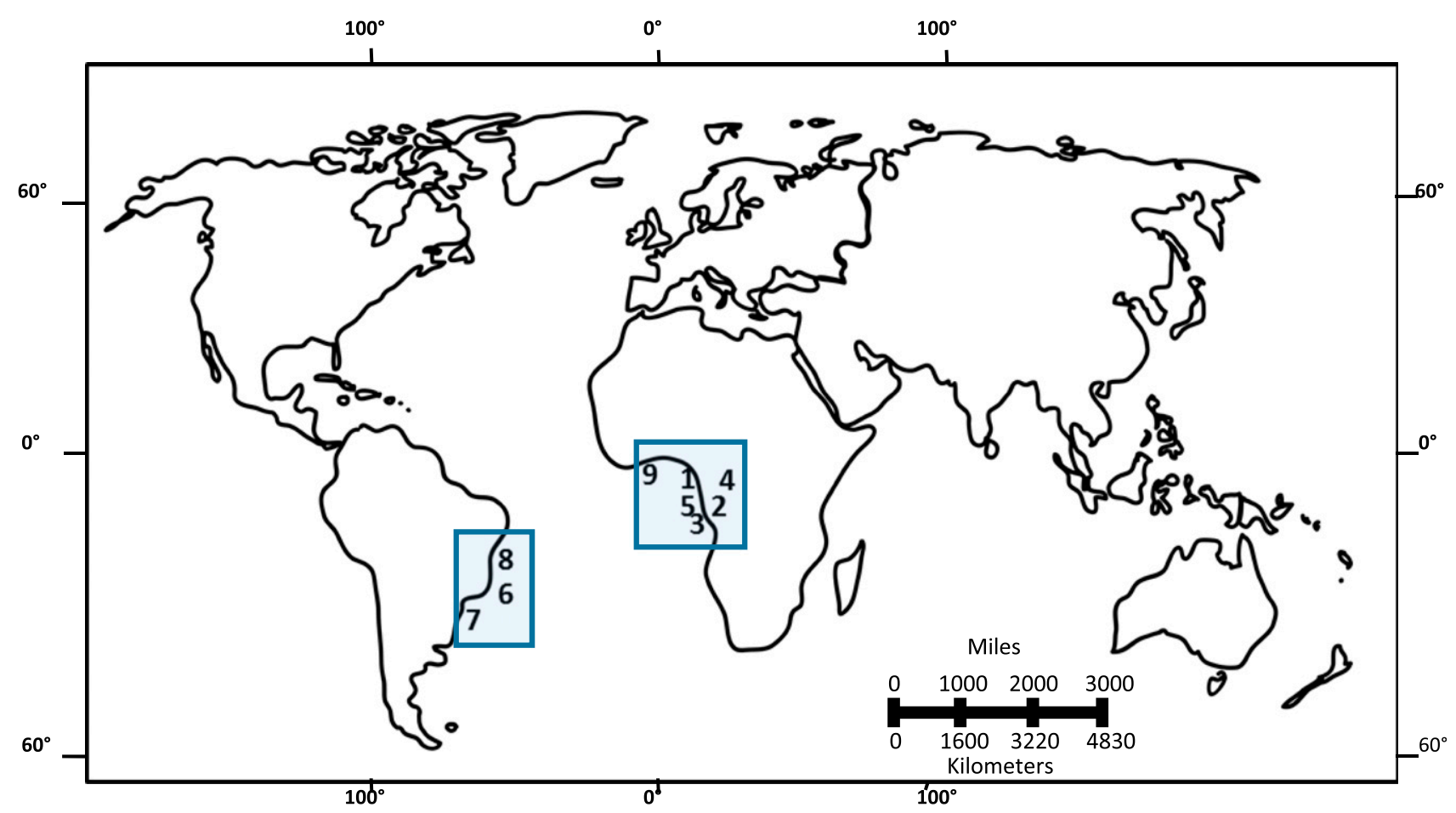

Figure 3. Location map of some important basins with Cretaceous source rocks from South Atlantic margin. 1 = Douala Basin; 2 = central and southern Congo Basin; 3 = offshore lower Congo Basin; 4 = northern Congo Basin; 5 = offshore southern Gabon Basin; 6 = Campos Basin; 7 = Santos Basin; 8 = Alameda Camamu Basin; $9=$ Tano Basin.

of up to $2 \mathrm{~d}$. The Agbada Formation sandstones are thus highly porous and permeable and serve as excellent reservoirs (Doust and Omatsola, 1990). The major risk during exploration in the basin is the seal (Doust and Omatsola, 1990).

The Niger Delta was formed under the influence of fluvial, wave, and tidal systems (Doust and Omatsola, 1990), whereas the reservoir unit (Agbada Formation) in the delta was mainly influenced by the fluvialdeltaic depositional system, with series of sand and marine shale units present (Allen, 1965; Weber and Daukoru, 1975; Evamy et al., 1978; Doust and Omatsola, 1990; Reijers, 2011). The lateral extent of reservoirs in this delta is highly variable and dependent on growth faults, with sand thicknesses greater in the downthrown blocks (Weber and Daukoru, 1975). The fluvial sands tend to be very coarse; however, it is the barrier bars that display high reservoir quality because they are generally well sorted, poorly cemented, and have very low reduction in porosity with depth of burial (Kulke, 1995; Tuttle et al., 1999). Turbidites and deep-sea channel sands are the most important reservoirs in the offshore Niger Delta, and these reservoirs in the delta have mostly been influenced by gravity flow (Beka and Oti, 1995) and submarine fans (Burke, 1972).

\section{METHODS AND MATERIALS}

Unraveling the history of potentially mixed oil samples from the Niger Delta was undertaken using several geochemical approaches generally based on the different hydrocarbon compound classes (i.e., gasoline-range hydrocarbons, normal alkanes and isoprenoids, diamondoids, aromatics, and sterane and hopane biomarkers). Standard geochemical procedures used for this work included deasphaltening, solid-phase extraction (SPE) separation, GC, and GCMS. Details on the analytical methods used are provided in the Appendix.

A total of 180 oil samples from 40 onshore oil fields in the Niger Delta Basin were analyzed for this study. The selection of the oil samples was based on sample availability and samples were from at least two points in most wells (i.e., a deep reservoir and a shallow reservoir). The oil samples were subdivided into the western delta (23 samples), central delta (75 samples), 
Table 1. Cretaceous Source Rocks from Some Coeval Basins along the South Atlantic Margin (Africa and South America)

\begin{tabular}{|c|c|c|c|}
\hline Formation & Basin & Country & Reference \\
\hline $\begin{array}{l}\text { Marine marls of the Logbadjeck } \\
\text { and Mungo Formations }\end{array}$ & Douala Basin & Cameroon & Brownfield and Charpentier (2006) \\
\hline $\begin{array}{l}\text { Marine marls and shales of the } \\
\text { labe Formation }\end{array}$ & $\begin{array}{l}\text { Central and Southern } \\
\text { Congo Basin }\end{array}$ & $\begin{array}{l}\text { Democratic Republic } \\
\text { of Congo }\end{array}$ & Brownfield and Charpentier (2006) \\
\hline $\begin{array}{l}\text { Lacustrine and marine source rocks } \\
\text { of the Bucomazi Formation }\end{array}$ & $\begin{array}{l}\text { Offshore Lower } \\
\text { Congo Basin }\end{array}$ & Angola & McHargue (1990) \\
\hline $\begin{array}{l}\text { Lacustrine source rocks of the Pointe } \\
\text { Noire Marl Formation }\end{array}$ & $\begin{array}{l}\text { Northern Congo } \\
\text { Basin }\end{array}$ & Republic of Congo & Baudouy and Legorjus (1991) \\
\hline $\begin{array}{l}\text { Lacustrine source rocks of the } \\
\text { Kissenda and Melania Formation }\end{array}$ & $\begin{array}{l}\text { Offshore Southern } \\
\text { Gabon Basin }\end{array}$ & Gabon & Teisserenc and Villemin (1990) \\
\hline $\begin{array}{l}\text { Lacustrine carbonates of the Lagoa } \\
\text { Feia Formation }\end{array}$ & Campos Basin & Brazil & $\begin{array}{l}\text { Coward et al. (1999); Schiefelbein } \\
\text { et al. (1999) }\end{array}$ \\
\hline $\begin{array}{l}\text { Marine and lacustrine shales of the } \\
\text { Guaratiba Formation }\end{array}$ & Santos Basin & Brazil & Coward et al. (1999) \\
\hline $\begin{array}{l}\text { Limestones and dark shale of the } \\
\text { Itaipe Formation }\end{array}$ & $\begin{array}{l}\text { Almada Camamu } \\
\text { Basin }\end{array}$ & Brazil & Coward et al. (1999) \\
\hline Shales of the Apollonian Formation & Tano Basin & Ghana & Atta-Peters and Garrey (2014) \\
\hline
\end{tabular}

eastern delta (29 samples), and southern delta (53 samples) to show the variations in the data obtained, by area (Figure 1).

\section{RESULTS AND DISCUSSION}

The study was based on the analysis and interpretation of the distributions of different hydrocarbon compound classes. The gasoline-range parameters are important because they can comprise approximately $30 \%$ of the hydrocarbon composition (Hunt et al., 1980). Diamondoid hydrocarbons are also important because their concentrations in oil generally increase with the onset of thermal cracking; thus, they can be used to assess maturity, mixing, cracking extent, source, and biodegradation (Dahl et al., 1999; Moldowan et al., 2015). Commonly employed sterane and hopane biomarkers and aromatic hydrocarbon molecular marker parameters were also used to help unravel relationships in the potentially mixed oils from the Niger Delta Basin. Biodegradation and evaporative fractionation effects are known to affect parameters based on these hydrocarbon fractions (e.g., Thompson, 1987, 1988; Peters and Moldowan 1991 ; J. A. Curiale and Bromley, 1996; Head et al., 2003); thus, they are taken into account during the interpretation.

\section{NIGER DELTA HYDROCARBON CHARACTERIZATION}

\section{Normal Alkanes and Isoprenoids}

Measurements of peaks were not possible for all the analyzed samples because of biodegradation; thus, biodegraded samples were generally ignored during interpretation. The average pristane (Pr)/phytane $(\mathrm{Ph})$ ratio for the central delta oil samples is 3.07 and the eastern delta oil samples is 2.69 , whereas that of the western delta oil samples is 2.44 and the southern delta oil samples is 2.99 (Table 2). The average $n$-heptadecane $\left(n-C_{17}\right) / n$-pentadecane $\left(n-C_{27}\right)$ ratio for the central delta oil samples is 0.86 and the eastern delta oil samples is 1.10 , whereas that of the western delta oil samples is 2.05 and the southern delta oil samples is 3.32 (Table 2).

Interpretation of the origins of the oil samples (nonbiodegraded) based on the distributions of normal alkanes and isoprenoid hydrocarbons suggests that they were primarily sourced by type III kerogen, with some contributions from mixed type II and III kerogens, deposited primarily in oxidizing environments with the possibility of some deposited in dysoxic environments (Figure 4). This interpretation was based on crossplots of $\mathrm{Pr} / \mathrm{n}-\mathrm{C}_{17}$ versus $\mathrm{Ph} / \mathrm{n}$-octadecane $\left(\mathrm{n}-\mathrm{C}_{18}\right)$, with samples having values greater than 1 
Table 2. List of Calculated Parameters for the Various Regions of Niger Delta Basin

\begin{tabular}{|c|c|c|c|c|c|c|c|c|c|}
\hline \multirow[b]{2}{*}{ Parameters } & \multicolumn{2}{|c|}{ Central Delta } & \multicolumn{2}{|c|}{ Southern Delta } & \multicolumn{2}{|c|}{ Eastern Delta } & \multicolumn{2}{|c|}{ Western Delta } & \multirow[b]{2}{*}{ NSO-1 } \\
\hline & Mean & SD & Mean & SD & Mean & SD & Mean & SD & \\
\hline $\mathrm{Pr} / \mathrm{Ph}$ & 3.07 & 0.63 & 2.99 & 0.56 & 2.69 & 0.47 & 2.44 & 0.65 & 1.55 \\
\hline $\mathrm{Pr} / \mathrm{n}-\mathrm{C}_{17}$ & 2.65 & 4.04 & 2.13 & 3.34 & 3.03 & 4.68 & 13.52 & 32.06 & 0.66 \\
\hline $\mathrm{Ph} / \mathrm{n}-\mathrm{C}_{18}$ & 1.15 & 2.20 & 1.03 & 1.70 & 1.04 & 1.29 & 2.82 & 2.81 & 0.54 \\
\hline$n-C_{17} / n-C_{27}$ & 0.86 & 0.91 & 3.32 & 0.09 & 1.10 & 1.29 & 2.05 & 0.93 & 5.81 \\
\hline$\% C_{27} \alpha \alpha \alpha$ sterane & 26.15 & 0.05 & 29.10 & 0.04 & 31.08 & 0.04 & 29.91 & 0.04 & 48.11 \\
\hline$\% C_{28} \alpha \alpha \alpha$ sterane & 26.29 & 0.02 & 27.62 & 0.03 & 28.54 & 0.02 & 27.32 & 0.03 & 18.92 \\
\hline$\% C_{29} \alpha \alpha \alpha$ sterane & 47.56 & 0.05 & 43.28 & 0.03 & 40.36 & 0.03 & 42.77 & 0.07 & 32.97 \\
\hline Sterane/hopane & 0.23 & 0.06 & 0.21 & 0.07 & 0.30 & 0.09 & 0.22 & 0.05 & 0.47 \\
\hline St29 S/R & 0.48 & 0.08 & 0.42 & 0.04 & 0.43 & 0.04 & 0.46 & 0.06 & 0.77 \\
\hline St29 I/R & 0.38 & 0.06 & 0.34 & 0.04 & 0.37 & 0.05 & 0.35 & 0.05 & 0.65 \\
\hline Pregnane ratio & 0.13 & 0.03 & 0.16 & 0.03 & 0.14 & 0.02 & 0.14 & 0.03 & 0.25 \\
\hline Diasterane ratio & 0.15 & 0.02 & 0.15 & 0.03 & 0.18 & 0.03 & 0.13 & 0.02 & 0.44 \\
\hline$\% \mathrm{C}_{29}$ hopane & 33.35 & 4.64 & 33.68 & 2.32 & 31.53 & 4.88 & 32.34 & 7.30 & 19.30 \\
\hline$\% C_{30}$ hopane & 48.78 & 4.91 & 49.36 & 2.38 & 49.81 & 4.43 & 48.34 & 5.64 & 50.44 \\
\hline$\% C_{31}$ hopane & 17.87 & 1.78 & 16.96 & 2.45 & 18.67 & 2.15 & 19.32 & 2.83 & 30.26 \\
\hline Hopane/moretane & 5.60 & 1.42 & 5.87 & 1.00 & 6.04 & 1.35 & 5.83 & 1.30 & 10.58 \\
\hline$C_{35} / C_{34}$ hopane & 0.56 & 0.13 & 0.45 & 0.13 & 0.52 & 0.11 & 0.52 & 0.12 & 0.74 \\
\hline $\mathrm{Ts} / \mathrm{Ts}+\mathrm{Tm}$ & 0.45 & 0.02 & 0.42 & 0.03 & 0.42 & 0.03 & 0.45 & 0.03 & 0.47 \\
\hline Oleanane index & 0.48 & 0.11 & 0.48 & 0.07 & 0.43 & 0.09 & 0.44 & 0.11 & - \\
\hline Diahopane/normoretane & 0.53 & 0.36 & 0.44 & 0.17 & 0.54 & 0.34 & 0.52 & 0.34 & 1.17 \\
\hline Heptane ratio & 13.97 & 4.28 & 14.86 & 6.25 & 13.51 & 7.39 & 14.93 & 7.98 & 23.95 \\
\hline Isoheptane ratio & 0.76 & 0.18 & 0.84 & 0.41 & 0.73 & 0.32 & 0.73 & 0.35 & 1.38 \\
\hline $\mathrm{cH} / \mathrm{bcC}_{7}$ & 63.07 & 10.76 & 55.16 & 5.70 & 52.28 & 8.31 & 58.48 & 1.24 & 53.67 \\
\hline $\mathrm{cP} / \mathrm{bcC}$ & 21.20 & 6.92 & 24.98 & 5.50 & 27.30 & 5.94 & 22.86 & 2.04 & 19.90 \\
\hline $\mathrm{b} / \mathrm{bcC}_{7}$ & 15.74 & 4.18 & 19.86 & 3.48 & 20.42 & 7.29 & 18.66 & 1.02 & 26.43 \\
\hline Toluene/n-heptane & 2.62 & 2.47 & 1.28 & 1.61 & 2.62 & 5.35 & 0.80 & 0.47 & 0.72 \\
\hline n-Heptane/methylcyclohexane & 0.34 & 0.13 & 0.39 & 0.16 & 0.35 & 0.19 & 0.41 & 0.22 & 0.79 \\
\hline $\mathrm{C}_{27}$ c-ring monoaromatic & 11.51 & 3.11 & 12.36 & 2.63 & 12.94 & 3.00 & 13.74 & 3.68 & - \\
\hline $\mathrm{C}_{28}$ c-ring monoaromatic & 48.57 & 5.76 & 44.81 & 8.28 & 47.98 & 6.50 & 47.02 & 7.04 & - \\
\hline $\mathrm{C}_{29}$ c-ring monoaromatic & 39.92 & 4.99 & 42.83 & 6.63 & 39.08 & 5.33 & 39.25 & 6.28 & - \\
\hline $\operatorname{Rc}(\operatorname{Ro}<1.35)$ & 0.91 & 0.15 & 0.84 & 0.08 & 0.85 & 0.09 & 0.87 & 0.10 & 0.80 \\
\hline MPI-2 & 0.82 & 0.23 & 0.72 & 0.13 & 0.73 & 0.14 & 0.76 & 0.16 & 0.77 \\
\hline $\mathrm{TMNr}$ & 0.56 & 0.15 & 0.55 & 0.13 & 0.59 & 0.09 & 0.52 & 0.20 & 0.71 \\
\hline TeMNr & 0.56 & 0.09 & 0.51 & 0.12 & 0.54 & 0.13 & 0.55 & 0.16 & 0.57 \\
\hline $\mathrm{PMNr}$ & 0.55 & 0.15 & 0.39 & 0.13 & 0.45 & 0.15 & 0.48 & 0.17 & 0.73 \\
\hline 4,9-DMD & 23.33 & 1.91 & 23.36 & 2.15 & 22.63 & 1.52 & 24.78 & 1.87 & 20.32 \\
\hline 4,8 DMD & 45.16 & 3.57 & 46.05 & 2.59 & 46.33 & 2.87 & 43.17 & 2.23 & 48.69 \\
\hline 3,4 DMD & 31.52 & 2.65 & 30.58 & 2.16 & 31.04 & 2.33 & 32.05 & 1.96 & 30.99 \\
\hline DMDI & 65.85 & 3.83 & 66.34 & 2.98 & 67.15 & 2.54 & 63.53 & 2.63 & 70.55 \\
\hline DMAI-1 & 0.64 & 2.13 & 0.60 & 2.01 & 0.58 & 1.99 & 0.59 & 1.98 & - \\
\hline EAI & 72.25 & 3.21 & 72.78 & 2.86 & 73.86 & 2.92 & 72.42 & 2.49 & - \\
\hline MAI & 65.37 & 4.83 & 64.96 & 6.82 & 65.76 & 3.40 & 68.29 & 1.81 & 45.12 \\
\hline MDI & 40.81 & 2.08 & 40.49 & 2.46 & 39.71 & 1.98 & 42.32 & 1.79 & 26.21 \\
\hline
\end{tabular}


Table 2. Continued

\begin{tabular}{|c|c|c|c|c|c|c|c|c|c|}
\hline \multirow[b]{2}{*}{ Parameters } & \multicolumn{2}{|c|}{ Central Delta } & \multicolumn{2}{|c|}{ Southern Delta } & \multicolumn{2}{|c|}{ Eastern Delta } & \multicolumn{2}{|c|}{ Western Delta } & \multirow[b]{2}{*}{ NSO-1 } \\
\hline & Mean & SD & Mean & SD & Mean & SD & Mean & SD & \\
\hline $3+4 \mathrm{MD}, \mathrm{ppm}$ & 46.36 & 27.34 & 37.22 & 25.93 & 19.22 & 13.97 & 35.80 & 23.64 & 2.04 \\
\hline $\mathrm{C}_{29} \alpha \alpha \alpha 20 \mathrm{R}, \mathrm{ppm}$ & 45.88 & 22.81 & 41.29 & 25.15 & 43.11 & 23.94 & 47.28 & 18.88 & 10.56 \\
\hline
\end{tabular}

Abbreviations: $-=$ not calculated or measured as a result of peak(s) absence; $\% C_{27} \alpha \alpha \alpha$ sterane $=C_{27} \alpha \alpha \alpha 20 R / C_{27-29} \alpha \alpha \alpha 20 R ; \% C_{28} \alpha \alpha \alpha$ sterane $=C_{28} \alpha \alpha \alpha 20 R / C_{27-29}$ $\alpha \alpha \alpha 20 \mathrm{R} ; \% \mathrm{C}_{29} \alpha \alpha \alpha$ sterane $=\mathrm{C}_{29} \alpha \alpha \alpha 20 \mathrm{R} / \mathrm{C}_{27-29} \alpha \alpha \alpha 20 \mathrm{R} ; \% \mathrm{C}_{29}$ hopane $=$ the ratio of $\mathrm{C}_{29}$ regular hopane to $\mathrm{C}_{29-31}$ regular hopanes; $\% \mathrm{C}_{30}$ hopane $=$ the ratio of $C_{30}$ regular hopane to $C_{29-31}$ regular hopanes; $\% C_{31}$ hopane $=$ the ratio of $C_{31}$ regular hopane to $C_{29-31}$ regular hopanes; $3+4 \mathrm{MD}=3$-methyldiamnatane +4 methyldiamantane; 3,4-DMD = 3,4-dimethyldiamantane/4,9- + 4,8- + 3,4-dimethyldiamantane; 4,8-DMD = 4,8-dimethyldiamantane/4,9- + 4,8- + 3,4-dimethyldiamantane; 4,9-DMD = 4,9-dimethyldiamantane/4,9- + 4,8- + 3,4-dimethyldiamantane; b/bcC ${ }_{7}=\mathrm{C}_{7}$ branched hydrocarbons/(branched + cyclic) $\mathrm{C}_{7}$ hydrocarbons; $\mathrm{C}_{29}$ $\alpha \alpha \alpha 20 \mathrm{R}=\mathrm{C}_{29} 5 \alpha(\mathrm{H}), 14 \alpha(\mathrm{H}), 17 \alpha(\mathrm{H})-20 \mathrm{R}$ stigmastane; $\mathrm{C}_{35} / \mathrm{C}_{34}$ hopane $=$ the ratio of $\mathrm{C}_{35}$ regular hopane to $\mathrm{C}_{34}$ regular hopane; $\mathrm{cH} / \mathrm{bcC} \mathrm{C}_{7}=\mathrm{cyclohexane} /(\mathrm{branched}+$ cyclic) $C_{7}$ hydrocarbons; $\mathrm{CP} / \mathrm{bcC} \mathrm{C}_{7}=$ cyclopentane/(branched + cyclic) $\mathrm{C}_{7}$ hydrocarbons; diasterane ratio $=\mathrm{C}_{27} \beta \alpha 20(\mathrm{~S}+\mathrm{R}) /\left(\mathrm{C}_{27} \beta \alpha 20[\mathrm{~S}+\mathrm{R}]+\mathrm{C}_{29} \alpha \alpha \alpha 20[\mathrm{~S}+\mathrm{R}]+\mathrm{C}_{29}\right.$ $\alpha \beta \beta$ 20[S + R]); DMAI-1 = 1,3-dimethyladamantane /1,2- + 1,3-dimethyladamantane; DMDI = 100(3,4-dimethyldiamantane/3,4- + 4,9-dimethyldiamantane); EAI = 100(2ethyladamantane/2- +1 -ethyladamnatane); heptane ratio $=$ the ratio of $n$-heptane to naphthenic heptanes; hopane/moretane $=$ the ratio of $17 \alpha(\mathrm{H}), 21 \beta(\mathrm{H})$-hopanes to $17 \beta(\mathrm{H}), 21 \alpha(\mathrm{H})$-moretanes; isoheptane ratio = (2-methyl hexane +3-methyl hexane)/(1cis3-dimethylcyclopentane + 1trans 3-dimethylcyclopentane+ 1trans 2dimethylcyclopentane); MAI = 100(1-methyadamantane/1- +2-methyladamantane); MDI = 100(4-methyldiamantane/4- + 1- +3-methyldiamantane); MPI-1 = 1.5(2- + 3methylphenanthrenes)/phenanthrene + 1- + 9- methylphenanthrenes; MPI-2 $=3\left(2\right.$-methylphenanthrenes)/phenanthrene $+1-+9$ - methylphenanthrenes; $\mathrm{n}-\mathrm{C}_{17} / \mathrm{n}-\mathrm{C}_{27}=$ ratio of $n$-heptadecane to $n$-pentadecane; NSO-1 = Norwegian Sea oil; oleanane index = the ratio of oleanane relative to $C_{30} \alpha \beta$ hopane; $\mathrm{Ph} / \mathrm{n}-\mathrm{C}_{18}=$ the ratio of phytane to n-octadecane; PMNr $=1,2,4,6,7$-pentamethylnaphthalane/1,2,4,6,7- + 1,2,3,5-6-pentamethylnaphthalane; pregnane ratio $=($ diginane $+5 \alpha$ pregnane +20 - methyldiginane $+5 \alpha$ methylpregnane $) /\left([\right.$ diginane $+5 \alpha$ pregnane +20 - methyldiginane $+5 \alpha$ methylpregnane $\left.]+\mathrm{C}_{29} \alpha \alpha \alpha 20[\mathrm{~S}+\mathrm{R}]+\mathrm{C}_{29} \alpha \beta \beta 20[\mathrm{~S}+\mathrm{R}]\right) ; \mathrm{Pr} / \mathrm{n}-\mathrm{C}_{17}=$ the ratio of pristane to $\mathrm{n}$-heptadecane; $\mathrm{Pr} / \mathrm{Ph}=$ the ratio of pristane to phytane; $\mathrm{Rc}=(0.6[\mathrm{MPI}-1]+0.4) ; \mathrm{Rc}(\mathrm{Ro}<1.35)=0.6(\mathrm{MPI}-1)+0.4 ; \mathrm{Ro}=$ vitrinite reflectance; $\mathrm{SD}=$ standard deviation; St29 I/R = the ratio of $C_{29}$ isosteranes to $C_{29}$ regular steranes; St29 S/R = the ratio of $C_{29}$ regular steranes $20 S$ to $C_{29}$ regular steranes $20 R$; sterane/ hopane $=\left[C_{27-29} \alpha \alpha \alpha(20 \mathrm{~S}+20 \mathrm{R})+\mathrm{C}_{27-29} \alpha \beta \beta(20 \mathrm{~S}+20 \mathrm{R})\right.$ steranes $] /\left[\mathrm{C}_{29-30} \alpha \beta+\mathrm{C}_{31-33} \alpha \beta(22 \mathrm{~S}+22 \mathrm{R})\right.$ hopanes $]$; TeMNr $=1,3,6,7-$ tetramethynapthalene/1,3,6,7- + 1,2,5,6- +1,2,3,6-tetramethylnaphthalanes; toluene/n-heptane $=$ the ratio of toluene to $\mathrm{n}$-heptane; TMNr $=1,3,7$-trimethynepthalene/1,3,7- $+1,2,5,7$-trimethynepthalene; $\mathrm{Ts} / \mathrm{Ts}+\mathrm{Tm}=$ the ratio of trisnorneohopane to trisnorhopane.

mostly being altered and biodegraded to some extent (e.g., Lijmbach, 1975; Alexander et al., 1981; Shanmugam, 1985) and not used for interpretation. In addition, 71 biodegraded samples, for which $\mathrm{n}-\mathrm{C}_{17}$ and $\mathrm{n}-\mathrm{C}_{18}$ peaks were not measurable, are not included in Figure 4 and are therefore not part of the source interpretation.

Thermal maturity interpretation based on normal alkane odd or even predominance of nonbiodegraded oil samples indicates that the samples are mainly of early thermal maturity, with carbon preference index (CPI) values (see Bray and Evans, 1961) between 1.05 and 1.20, and some are thermally mature with CPI values approximately 1.00 (i.e., $\sim 0.95-1.05$ ). It is known, however, that terrigenousinfluenced oils commonly have higher CPI values than those of marine oils (Scalan and Smith, 1970).

Normal alkane profiles of the nonbiodegraded hydrocarbons from the different regions of the delta appear very distinct, especially when the ratio of $\mathrm{n}-\mathrm{C}_{17}$ to $\mathrm{n}-\mathrm{C}_{27}$ is compared in the different oils (Figure 5). This ratio helps to indicate the relative abundances of microbial and algal versus terrestrial higher plant contributions (Eglinton and Hamilton, 1967; Gelpi et al., 1970; Burwood et al., 2003). Notwithstanding possible effects of thermal maturity and biodegradation, this ratio indicates that there is a relatively high terrestrial plant contribution in the central delta oil samples and a low one in the southern and western delta oils, whereas the eastern delta oil samples have equal contributions of both inputs (Figure 5).

\section{Sterane and Hopane Biomarkers}

No marked variations exist in most calculated sterane and hopane parameters, with the exception of those of the $\mathrm{C}_{29} \alpha \alpha \alpha 20 \mathrm{R} / \mathrm{C}_{27-29} \alpha \alpha \alpha$ 20R (\% $\mathrm{C}_{29} \alpha \alpha \alpha$ steranes), sterane/hopane ratio, oleanane index, and diahopane/normoretane ratio. The $\% \mathrm{C}_{29} \alpha \alpha \alpha$ sterane averages for the central, southern, eastern, and western delta oil samples are $47.6 \%, 43.3 \%, 40.4 \%$, and $42.8 \%$, respectively. A distinct elevation exists in the average sterane/hopane ratio of samples from the eastern delta oil (0.30), whereas the range of the averages from the other parts of the delta is $0.21-0.23$ (Table 2).

The average oleanane ratio for central and southern delta oil samples is 0.48 , whereas that of the western delta is 0.44 and the southern delta is 0.43 . This ratio can be influenced by biodegradation because oleanane is more resistant to biodegradation in comparison to the $\mathrm{C}_{30} \alpha \beta$ hopane (Frontera-Suau et al., 2002; Wenger 


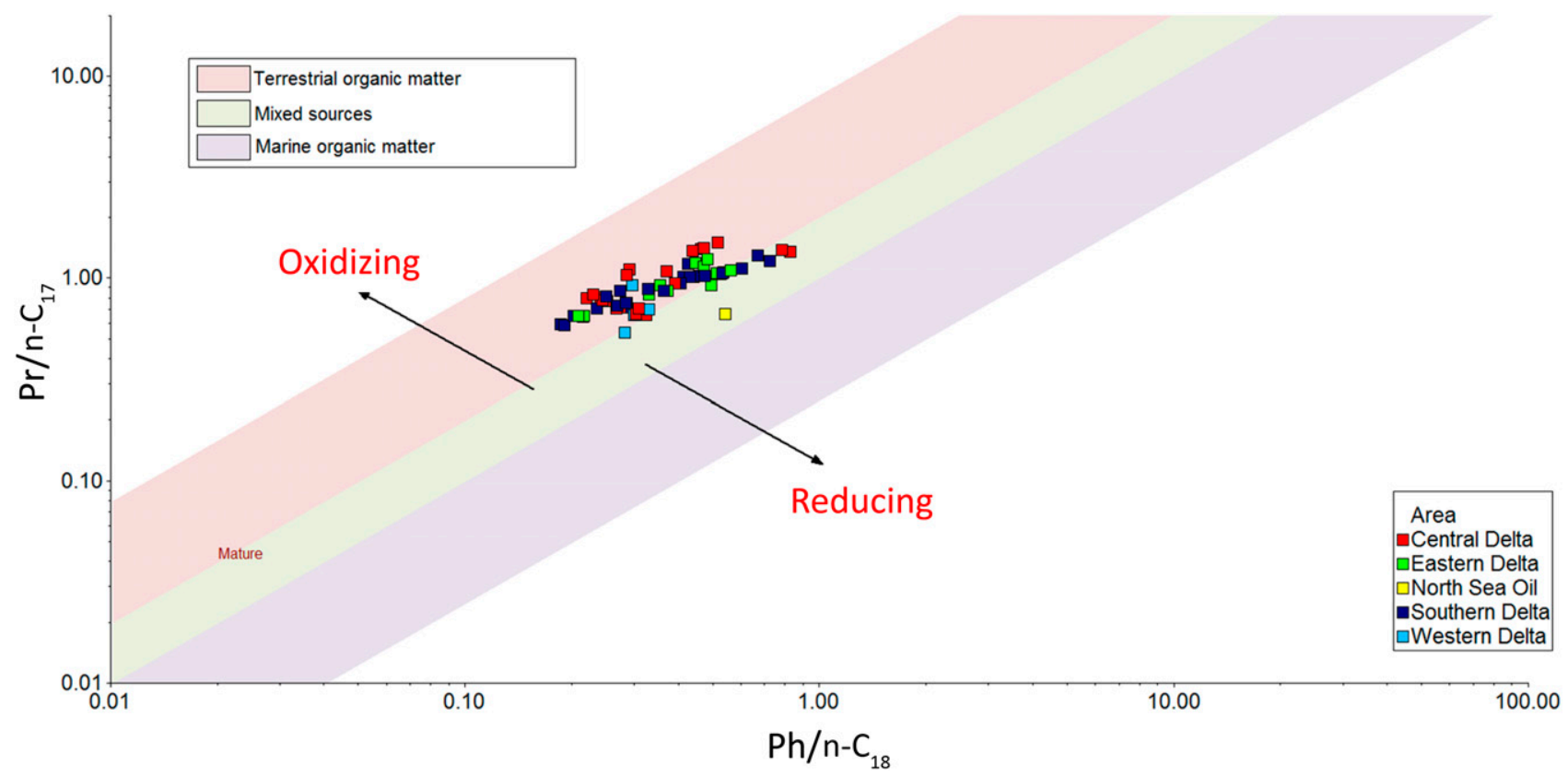

Figure 4. Crossplot of pristane $(\mathrm{Pr}) / \mathrm{n}$-heptadecane $\left(n-C_{17}\right)$ against phytane $(\mathrm{Ph}) / \mathrm{n}$-octadecane $\left(n-\mathrm{C}_{18}\right)$ ratios of oil samples from the different Niger Delta areas showing the source kerogen type and depositional environment. Interpretation overlay from Integrated Geochemical Interpretation 3.5 software (modified after Shanmugam, 1985).

et al., 2002). The average diahopane/normoretane ratio is similar for central, eastern, and western delta oil samples (i.e., between 0.52 and 0.54 ), whereas the average ratio for the southern delta oil samples is 0.44 (Table 2).

Sterane biomarker distributions (Figure 6) in the oil samples indicate they are derived from mixed planktonic-bacterial and land-plant source input (see Huang and Meinschein, 1979). The central delta oils appear to have more land-plant input, whereas the western delta oil samples appear to have less landplant input and are derived from source rocks that were deposited in either open-marine, shallow-marine, or deltaic depositional settings (Figure 7), with most

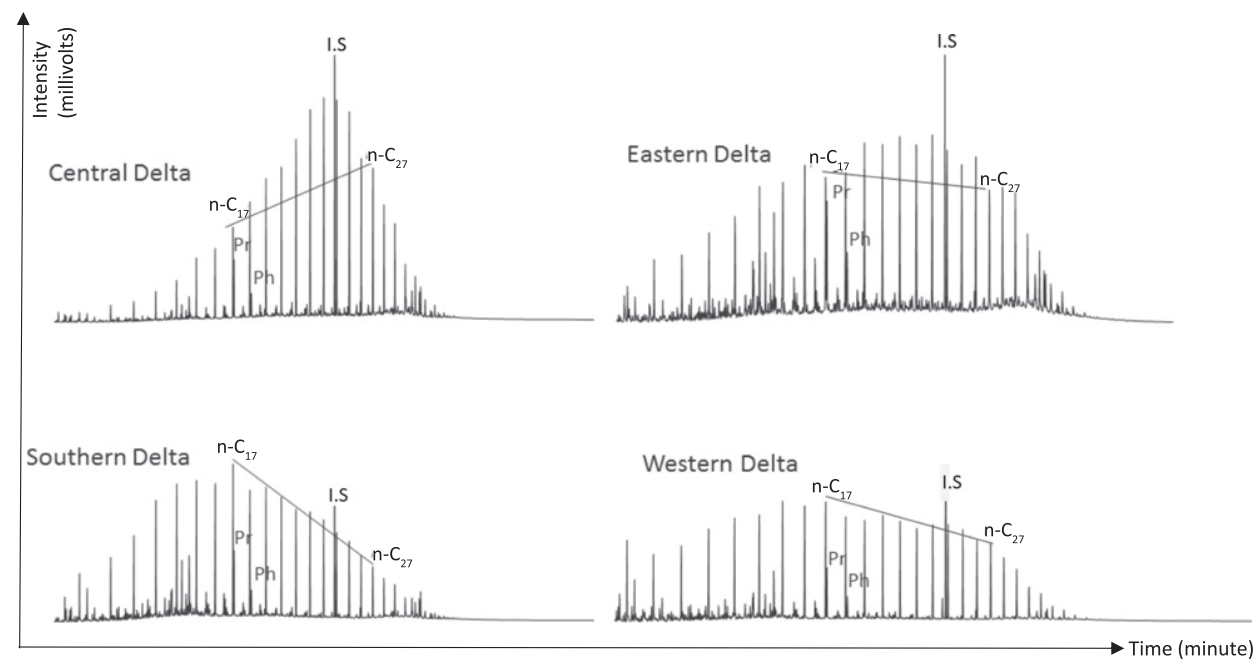

Figure 5. Representative n-alkane profiles of nonbiodegraded oils from the various regions of the Niger Delta. Note the different profiles, especially the relationship between $n$-heptadecane $\left(n-C_{17}\right)$ and $n$-pentadecane $\left(n-C_{27}\right)$ peaks. I.S = internal standard; $P r=$ pristane; $\mathrm{Ph}=$ phytane. 


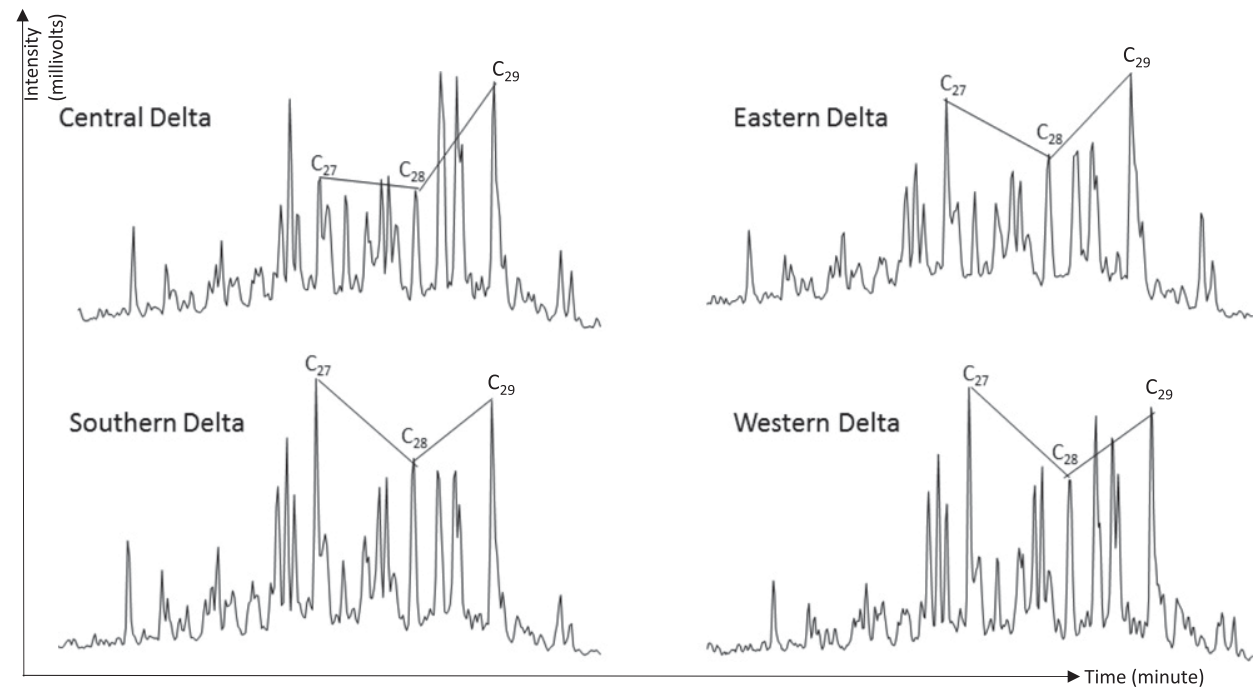

Figure 6. Representative partial mass-to-charge ratio 217 mass chromatograms showing the distributions of diasteranes and regular steranes in the oil samples from the various regions of the Niger Delta. Note the distribution of the $\mathrm{C}_{27-29} \alpha \alpha \alpha$ 20R steranes in the oil samples.

deposited in shallow-marine and some in deltaic depositional settings. However, it can be concluded that all of the Niger Delta oil samples have a notable terrigenous influence. Most eastern Niger Delta oil samples generally have more marine influence than the others, with the exception of five samples (Figure 8).
All studied oil samples have oleanane present (the oleanane index ranges from 0.29 to 0.86 , with an average of 0.47 ), which supports terrigenous organic matter input. However, the oleanane index (oleanane/ oleanane $+\mathrm{C}_{30} \alpha \beta$ hopane) values do not have a strong correlation with the sterane source depositional environment interpretation. This can be because of several
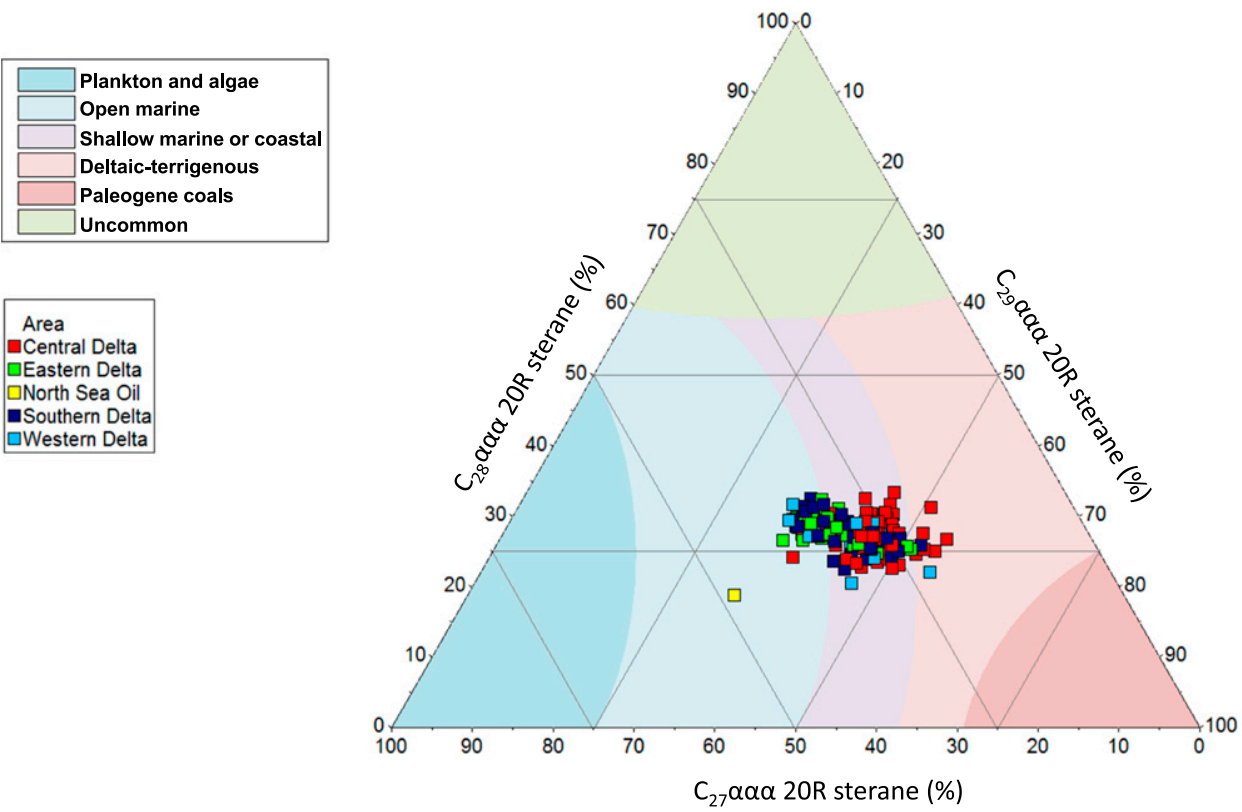

Figure 7. Ternary diagram showing the distribution of $C_{27} \alpha \alpha \alpha 20 R, C_{28} \alpha \alpha \alpha 20 R$, and $C_{29} \alpha \alpha \alpha$ 20R regular steranes in the Niger Delta oil samples. Depositional environment interpretational overlay for Integrated Geochemical Interpretation 3.5 software (modified after Huang and Meinschein, 1979). Five Niger Delta oil samples biodegraded to level 6 or higher, as described in Peters and Moldowan (1991), were excluded from the plot. 


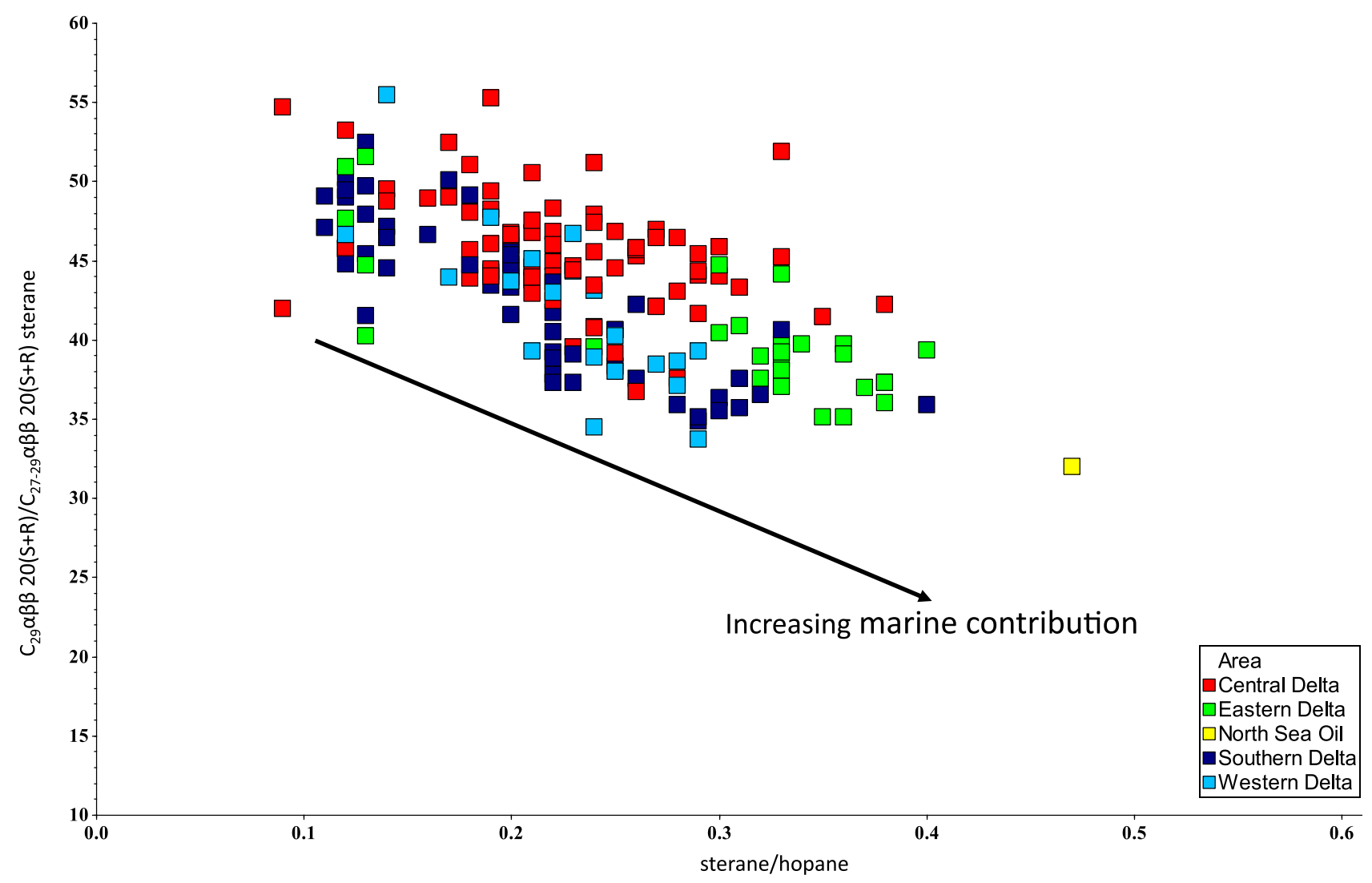

Figure 8. Plot of percentage $C_{29} \alpha \beta \beta 20(S+R) / C_{27}{ }_{29} \alpha \beta \beta 20(S+R)$ steranes against sterane/hopane ratios $\left[C_{27-29} \alpha \alpha \alpha(20 S+20 R)+\right.$ $\mathrm{C}_{27-29} \alpha \beta \beta(20 \mathrm{~S}+20 \mathrm{R})$ steranes $] /\left[\mathrm{C}_{29-30} \alpha \beta+\mathrm{C}_{31-33} \alpha \beta(22 \mathrm{~S}+22 \mathrm{R})\right.$ hopanes], showing marine contributions to the Niger Delta oil samples. Five Niger Delta oil samples biodegraded to level 6 or above, as described in Peters and Moldowan (1991), were excluded from the plot.

factors including that oleanane preservation increases to a maximum when deposition occurs in a marine setting (Ekweozor and Telnaes, 1990) and that oleanane index values are known to be dependent on thermal maturity (Ekweozor and Telnaes, 1990) and elevated oleanane index as a result of oleanane being more resistance to biodegradation in comparison to $\mathrm{C}_{30} \alpha \beta$ hopane (Frontera-Suau et al., 2002; Wenger et al., 2002). Oleanane preservation is enhanced if the precursors are deposited in deltaic environments and diagenesis takes place while the area is under marine transgression (e.g., Beaufort Sea, reported by McCaffrey et al., 1994; Mahakam Delta, reported by Peters et al., 2000), which is true of the Niger Delta Basin.

Most of the oil samples in this study were sourced primarily from rocks deposited in relatively oxic environments as inferred from $\mathrm{C}_{35} / \mathrm{C}_{34}$ hopane ratios (0.1-0.5) and some were sourced during periods of suboxic to dysoxic conditions (0.5-0.6) (see ten Haven et al., 1987). The ternary plot of $\mathrm{C}_{29-31} 17 \alpha(\mathrm{H})$-hopane proportions (Figure 9) shows that the oil samples were sourced from a marine shale, although there is a possibility that some samples may have been sourced from lacustrine environments.

Sterane isomerization parameters show that the Niger Delta oils are of relatively low thermal maturity (heavily biodegraded oils above level 5, as described in Peters and Moldowan, 1991, were not included) in comparison to the thermally mature North Sea oil (Figures 10, 11). This result is consistent with the work of Sonibare et al. (2008) and Akinlua and Ajayi (2009).

Several unsaturated compounds, including oleanane, bauer-7-ene, urs-12-ene, and so forth, have been reported in Niger Delta oils (Ekweozor and Udo, 1988; Ukpabio et al., 1994) and are attributed to migration and in-reservoir contamination from thermally immature Agbada shales (Ukpabio et al., 1994). Migration contamination is known to cause low sterane epimer maturity ratios because of the addition of immature hydrocarbons to mature oil. 


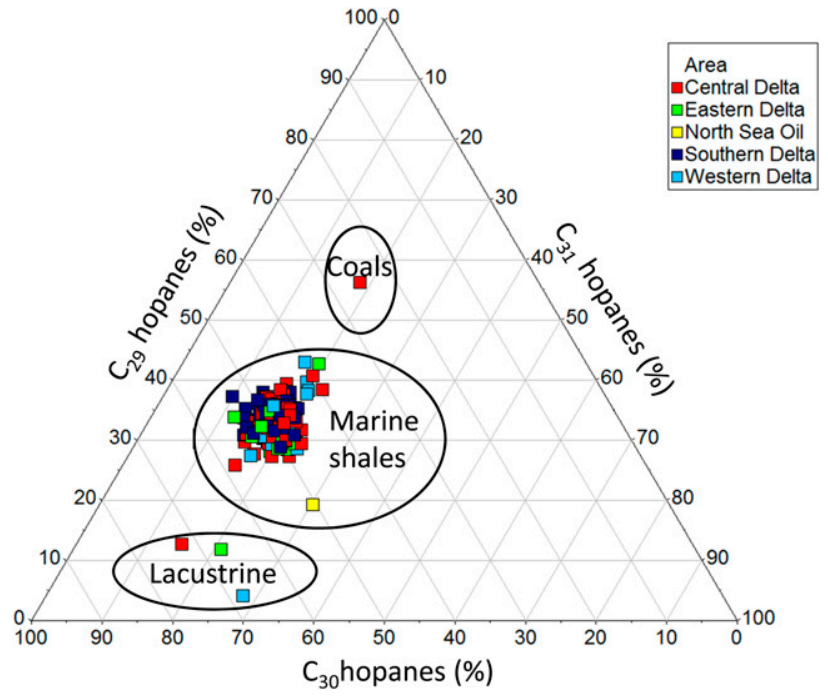

Figure 9. Ternary diagram showing the distribution of $C_{29}$, $C_{30}$, and $C_{31}$ hopanes in the Niger Delta oil samples, indicating that they were sourced from marine shales (see Killops et al., 1998).

This has been seen in a wide range of samples around the world, especially in Paleogene-Neogene deltas, (e.g., Hoffmann et al., 1984; J. A. Curiale and Bromley, 1996; J. Curiale et al., 2005) and is thought to have affected the oils of the Niger Delta Basin.
The $\mathrm{C}_{29} 5 \alpha, 14 \alpha, 17 \alpha(\mathrm{H})-20 \mathrm{~S} /(20 \mathrm{~S}+20 \mathrm{R})$ sterane isomerization and $\beta \beta /(\beta \beta+\alpha \alpha)$ isomerization at chiral position 14 and 17 in the $C_{29}$ steranes are known to be valid maturity indicators from the immature to peak oil window (Seifert and Moldowan, 1986). However, a plot of the diasterane/sterane ratio (total $\mathrm{C}_{27-29} 13 \beta, 17 \alpha(\mathrm{H}) 20 \mathrm{~S}+20 \mathrm{R}$ diasteranes/total $\mathrm{C}_{27-29} 5 \alpha, 14 \beta, 17 \beta(\mathrm{H})$ and $5 \alpha, 14 \alpha, 17 \alpha(\mathrm{H}) 20 \mathrm{~S}+$ 20R) against the pregnane ratio $\left(\mathrm{C}_{21}+\mathrm{C}_{22}\right.$ regular sterane/total $\mathrm{C}_{29}$ steranes) was used to further crosscheck thermal maturity results because both of these ratios are valid from immature to late oil window (Mackenzie, 1984; Cornford et al., 1988; Peters and Moldowan, 1991). The abundance of pregnanes increases with increasing thermal maturity relative to regular steranes, whereas diasteranes are more stable than regular steranes (Mackenzie, 1984; Cornford et al., 1988; Obermajer et al., 1996). These results (Figure 11) show that the Niger Delta oil samples appear to be of low thermal maturity compared to those of the North Sea oil. The 22,29,30-trisnor-17 $\alpha$-hopane (Tm) and 22,29,30-trisnor-18 $\alpha$-hopane (Ts) ratio $(\mathrm{Ts} /[\mathrm{Ts}+\mathrm{Tm}])$ indicates that the Niger Delta oil samples are of midmaturity (Moldowan et al., 1986). The hopane/moretane (Peters and Moldowan, 1991) and the diahopane/normoretane ratios, which are

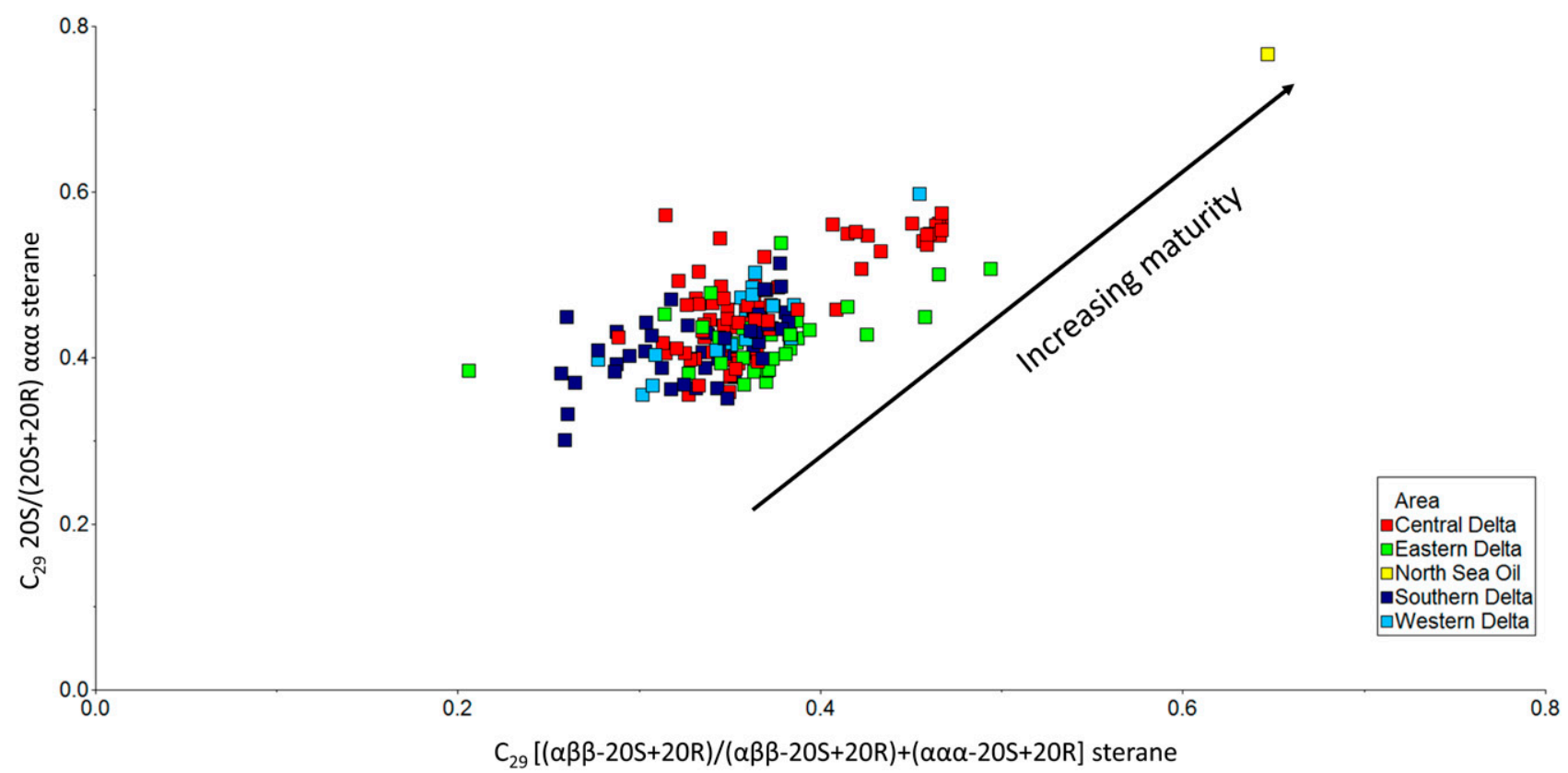

Figure 10. Plot of $C_{29} 20 S /(20 S+20 R) \alpha \alpha \alpha$ sterane against $C_{29}[(\alpha \beta \beta-20 S+20 R) /(\alpha \beta \beta-20 S+20 R)+(\alpha \alpha \alpha-20 S+20 R)]$ sterane isomerization maturity parameters showing that most of the Niger Delta oil samples appear to be of low maturity. Five Niger Delta oil samples biodegraded up to level 6, as described in Peters and Moldowan (1991), were excluded from the plot (modified after Seifert and Moldowan, 1986). 


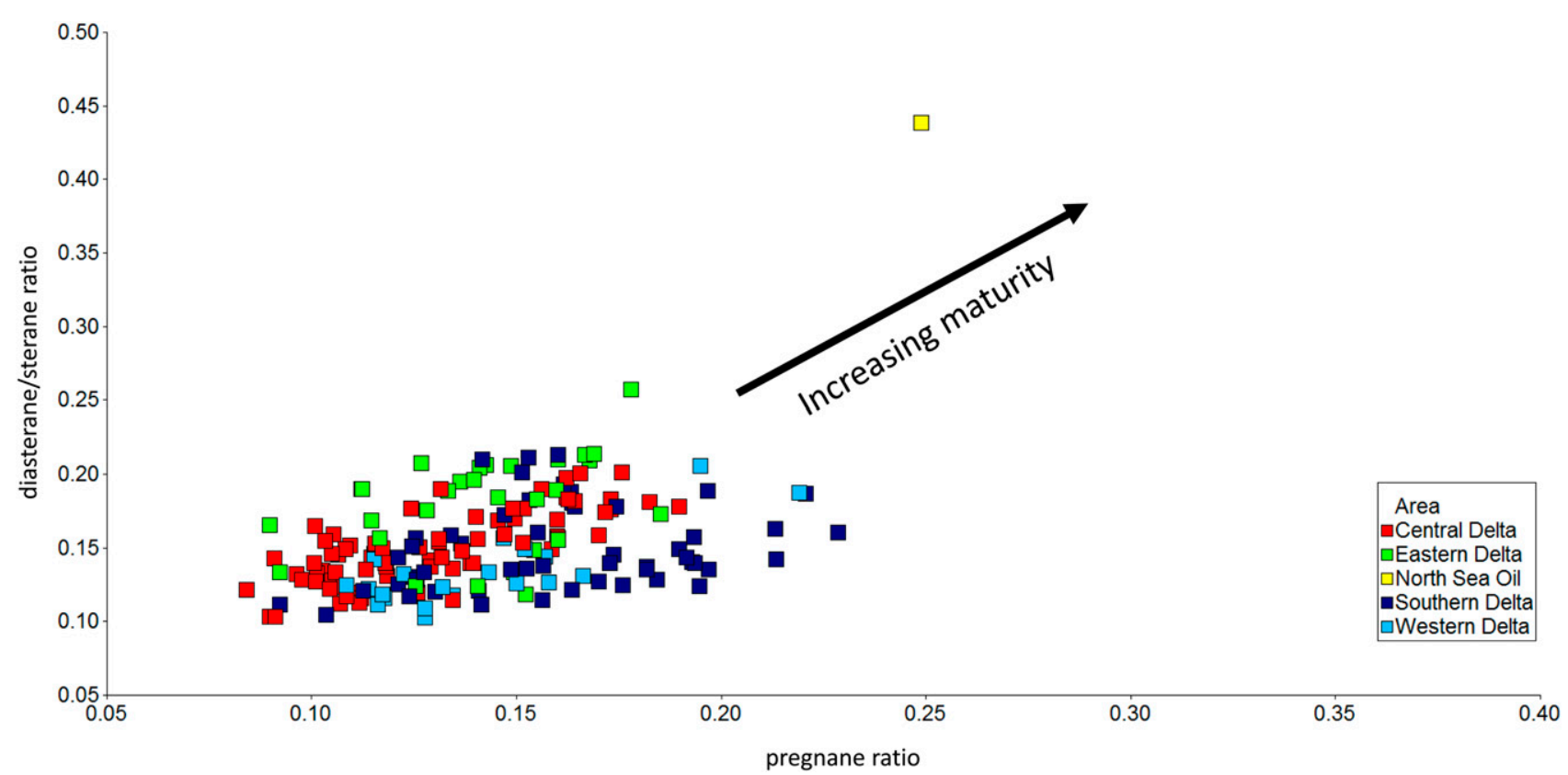

Figure 11. Plot of $C_{27} \beta \alpha 20(S+R) /\left[C_{27} \beta \alpha 20(S+R)+C_{29} \alpha \alpha \alpha 20(S+R)+C_{29} \alpha \beta \beta 20(S+R)\right.$ (diasterane/sterane ratios) against (diginane $+5 \alpha$ pregnane +20 -methyldiginane $+5 \alpha$ methylpregnane)/[(diginane $+5 \alpha$ pregnane +20 -methyldiginane $+5 \alpha$ methylpregnane) $\left.+\left(\mathrm{C}_{29} \alpha \alpha \alpha 20(\mathrm{~S}+\mathrm{R})+\mathrm{C}_{29} \alpha \beta \beta 20(\mathrm{~S}+\mathrm{R})\right)\right]$ (pregnane ratios), showing that most of the Niger Delta oil samples appear of lower maturity than the those of the thermally mature North Sea oil. Five Niger Delta oil samples biodegraded up to level 6 , as described in Peters and Moldowan (1991), were excluded from the plot.

more indicative for immaturity to early oil generation (Seifert and Moldowan 1980), show that the Niger Delta oil samples are mainly of low thermal maturity (Figure 12).

It is possible that the apparent low maturity indicated by these sterane and hopane epimers might be influenced by the presence of less mature transgressive shales in the Paleogene-Neogene reservoir sands of the delta and that these less mature to immature sterane and hopane distributions might have been picked up during oil migration or during its residence time in the reservoirs (see J. A. Curiale, 2002).

Four of the oils were heavily biodegraded and showed altered sterane distributions, although, interestingly, the $\mathrm{C}_{29}$ steranes in these samples were depleted relative to the $\mathrm{C}_{27}$ compounds, which is the opposite of what is normally reported because of biodegradation (e.g., Goodwin et al., 1983). The biodegradation effect on these source-indicating ratios of these four samples meant that they could not be used for the interpretation of their potential sources. However, the relative decrease of $\mathrm{C}_{29}$ steranes apparently caused by biodegradation does not affect the measured thermal maturity parameters (including those from aromatics and diamondoids).

\section{Gasoline-Range Hydrocarbons}

The average percentage heptane values for eastern and central delta oil samples are 13.5 and 14.0, respectively, whereas the average percentage heptane value for the southern and western delta oil samples is 14.9 (Table 2). The average toluene/n-heptane ratio for the central and eastern delta oil samples is 2.6, whereas the ratio for the western delta oil samples is 0.8 and the southern delta oil samples is 1.28 , as shown in Table 2 .

Gasoline-range hydrocarbons were measured on the nonbiodegraded oil samples (as shown by the normal alkane profiles in their saturated hydrocarbon fractions), and they indicate that the oils were sourced from type II and some mixed type II and III kerogens, with the reference North Sea oil also sourced from type II kerogen (Figure 13), deposited mainly in marine environments. Partial whole oil chromatograms show the central delta oils have relatively high abundances of benzene and toluene, indicating a more terrigenous influence, compared to oils from the eastern, southern, and western delta that have relatively low abundances of benzene and toluene but high abundances of cyclohexane and methylcyclohexane (Figure 14). The eastern delta oils show the most 


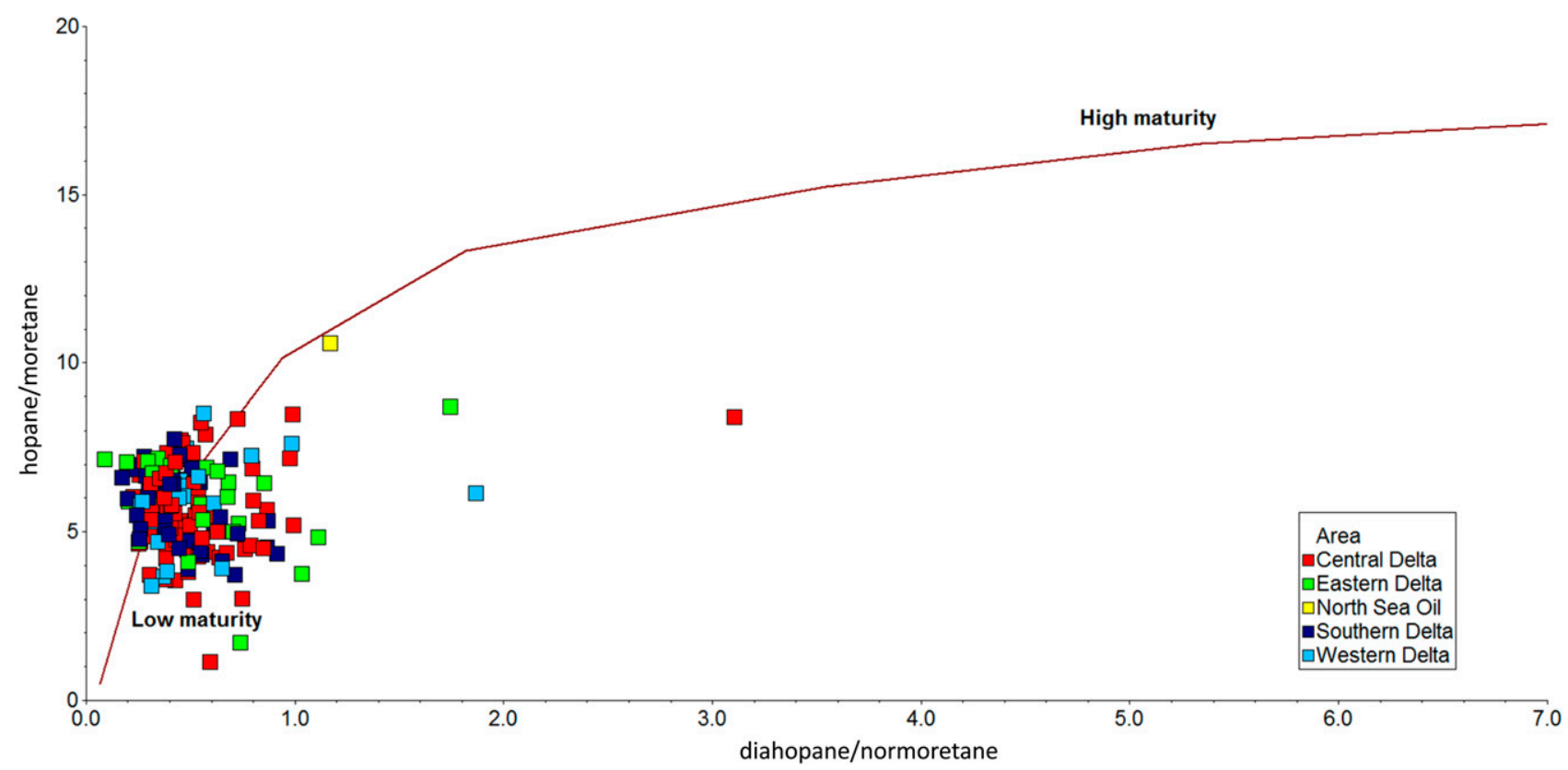

Figure 12. Plot of hopane/moretane against diahopane/normoretane hopane ratio maturity parameters. These indicate that most of the samples are of low maturity. Interpretation overlay for Integrated Geochemical Interpretation 3.5 software. Red line is the expected maturity trend.

depleted benzene and toluene contents, whereas the elevated cyclohexane/(branched + cyclic) $\mathrm{C}_{7}$ hydrocarbon ratio also supports indication that the central delta oil samples were from a more terrigenous source rock (Figure 15).
The Niger Delta oil samples appear mainly as mature oils based on heptane and isoheptane values, with most of the samples from all the regions plotting in this field in Figure 16 and with thermal maturities just a little lower than the North Sea

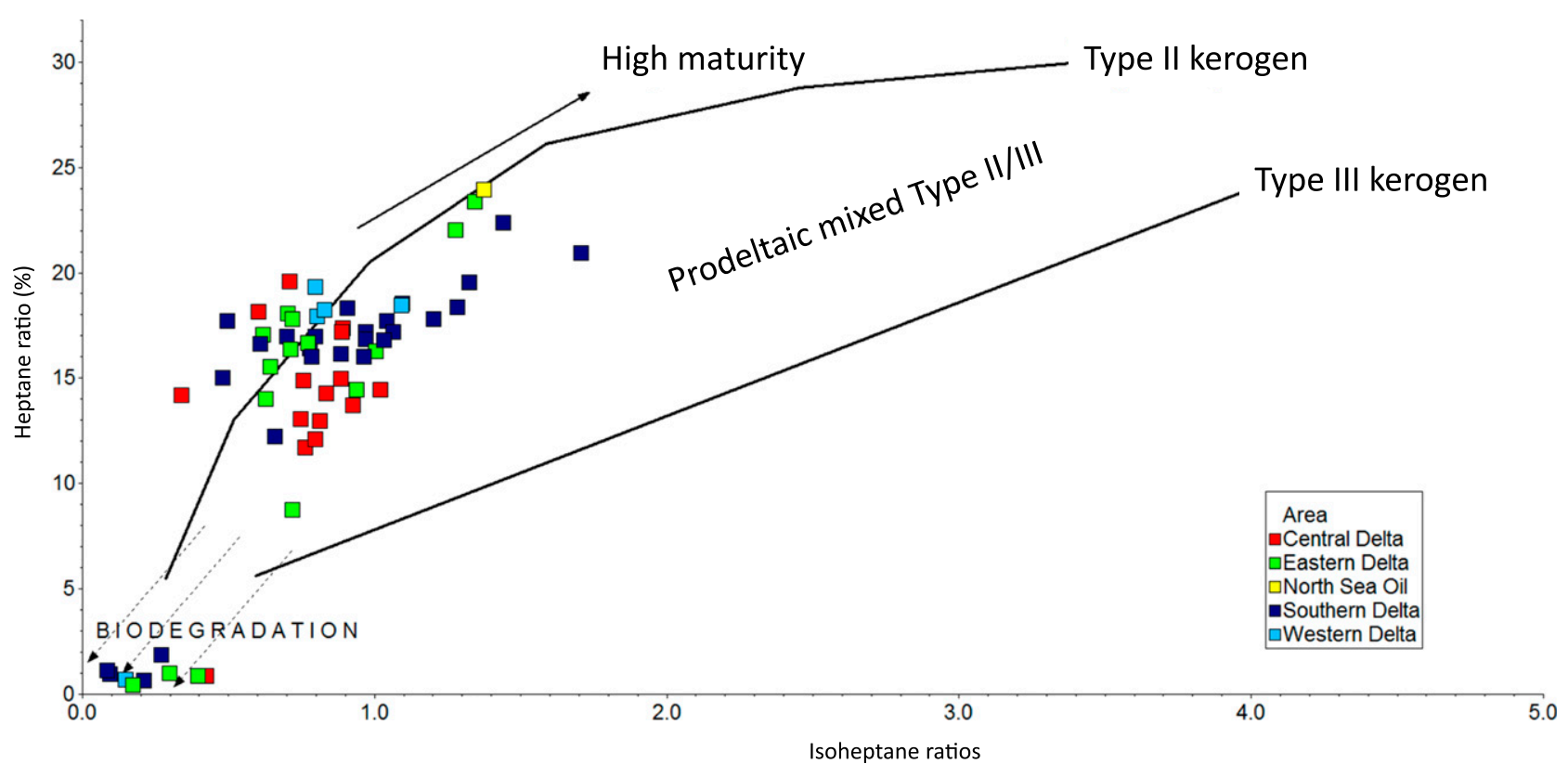

Figure 13. Plot of $n$-heptane/naphthenic heptanes (heptane ratio) versus [(2-methylhexane +3 -methylhexane)/(1cis3-dimethylcyclopentane + 1trans 3-dimethylcyclopentane + 1trans 2-dimethylcyclopentane)] (isoheptane ratios) of oil samples from the different areas of Niger Delta showing the source kerogen type. The oil samples appear to be mainly from type II and mixtures of type II and III kerogens. Note the absence of indications of any pure type III kerogens. Interpretation overlay from Integrated Geochemical Interpretation 3.5 software (modified after Thompson, 1983). Solid lines show the kerogen trends, while dotted lines show biodegradation trends. 


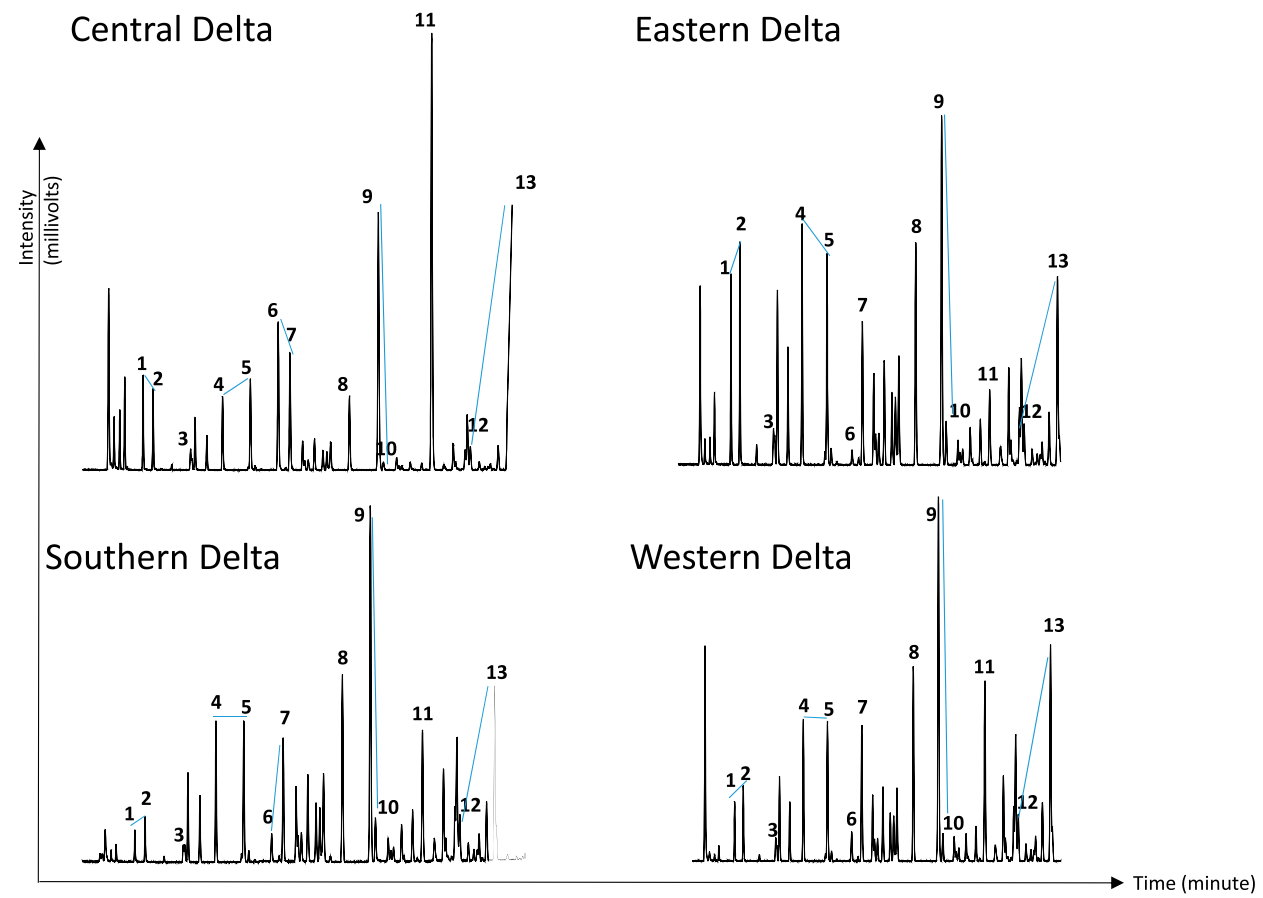

Figure 14. Representative partial whole oil gas chromatography-mass spectrometry total ion count chromatograms showing the light hydrocarbons from various regions of the Niger Delta. Note the differences in the relative peak intensities. Solid blue line shows peak variation and helps visual representation for comparison between areas of the delta. $1=$ isopentane $\left(C_{5}\right.$ monobranched $) ; 2=n$-pentane $\left(C_{5}\right.$ straight $) ; 3$ = cyclopentane $\left(\mathrm{C}_{5}\right.$ cyclo); $4=\mathrm{n}$-hexane $\left(\mathrm{C}_{6}\right.$ straight $) ; 5=$ methylcyclopentane $\left(\mathrm{C}_{6}\right.$ cyclo); $6=$ benzene $\left(\mathrm{C}_{6}\right.$ aromatic $) ; 7=\mathrm{n}$ heptane $\left(C_{7}\right.$ straight); $8=$ cyclohexane $\left(C_{6}\right.$ cyclo); $9=$ methylcyclohexane $\left(C_{7}\right.$ cyclo); $10=1$-cis-2-dimethylcyclopentane $\left(C_{7}\right.$ cyclo $)$; 11 = toluene; $12=3$-methylheptane; $13=$ n-octane.

oil. Based on these heptane and isoheptane values from Thompson (1987), for thermal maturity, it is indicated that none of the Niger Delta oil samples are late mature and none of them have been thermally cracked (Figure 16).

Nine samples suffered migration fractionation and were excluded from all the interpretations because of loss of n-heptane and methylhexanes that tend to partition more favorably into the gaseous phase and result in enrichment of aromatics in the residual oil (Thompson, 1987). Thus, the nine fractionated oil samples were not considered during the overall interpretation.

\section{Aromatic Hydrocarbons}

There were no major variations in the measured aromatic ratios of the samples analyzed (Table 2). The relatively low abundance of $\mathrm{C}_{29}$ monoaromatic steroids in the Niger Delta oils indicates that the oil samples were primarily sourced by marine shales. A few samples display more terrigenous sources as indicated by their relatively elevated $\mathrm{C}_{29}$ monoaromatic steroid proportions (Figure 17). The aromatic hydrocarbon distributions measured did not appear to have been significantly affected by biodegradation, even in the four most degraded samples mentioned earlier.

Values of equivalent vitrinite reflectance $\left(R_{o e}\right)$ calculated from the methylphenanthrene index and plotted against methylphenanthrene index 2 indicate that the Niger Delta oils are of peak to late oil window maturity $\left(R_{o e}\right.$ of $\left.0.65-1.30\right)$ (Figure 18). These estimates contrast with the results of the thermal maturity estimates from normal alkanes, gasoline range, sterane, and hopane biomarkers.

A ternary plot of pentamethylnaphthalene ratio (PMNr), tetramethylnaphthalene ratio (TeMNr), and trimethylnaphthalene ratio (TMNr) values should have all oil samples plotting inside the maturity center if the oil has not been mixed (mixed oil plots toward TMNr) or biodegraded (biodegraded oil plots toward TeMNr) (van Aarssen et al., 1999). However, most of the Niger Delta samples plot outside the maturity center (Figure 19) toward the TMNr axis, indicating that they are mixtures of different maturity oils (see van Aarssen et al., 1999). Some samples, including 


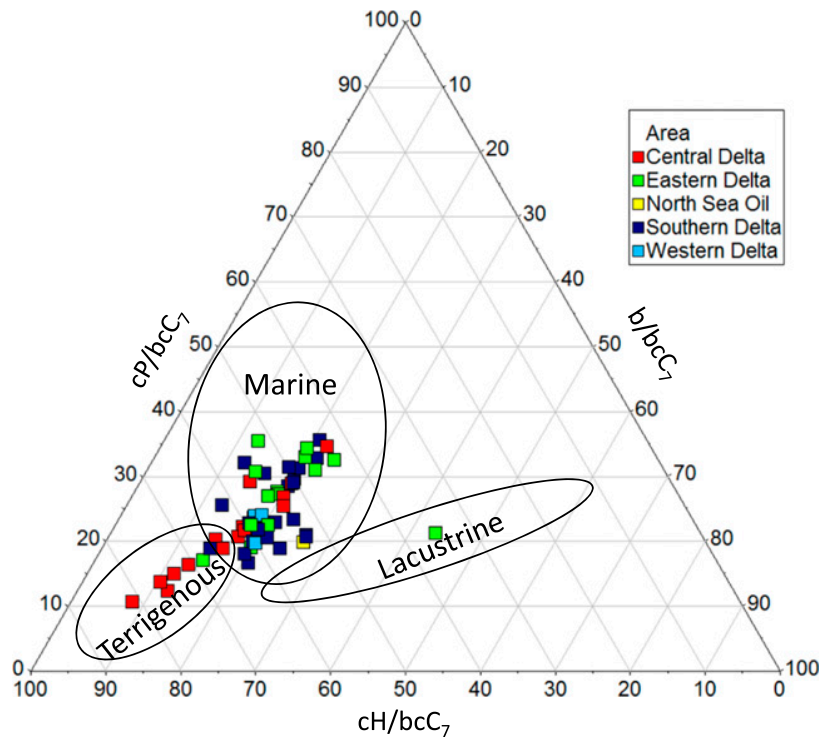

Figure 15. Ternary plot of the Mango (1997) ring-preference parameters ([cyclopentane/(branched + cyclic) $\mathrm{C}_{7}$ hydrocarbons] $\left[\mathrm{cP} / \mathrm{bcC}_{7}\right] ;\left[\mathrm{C}_{7}\right.$ branched hydrocarbons/(branched + cyclic) $\mathrm{C}_{7}$ hydrocarbons], [b/bcC $\mathrm{C}_{7}$; and [cyclohexane/(branched + cyclic) $\mathrm{C}_{7}$ hydrocarbons] $\left[\mathrm{cH} / \mathrm{bcC}_{7}\right]$ ), indicating possible source depositional environments of Niger Delta oils (see Ten Haven, 1996).

the North Sea oil, plot inside the maturity center, indicating that those oil samples have not been mixed, although it is not clear how a mixed oil sample will behave if the maturities of the contributing sources are similar.

\section{Diamondoid Hydrocarbons}

No marked variation exists for most of the calculated diamondoid ratios when comparing the samples from different parts of the delta; however, the 3-methyldiamnatane + 4-methyldiamantane $(3+4$ MD) concentrations show some marked variations especially in the eastern delta oils. The average $3+4$ MD concentrations for samples from the eastern, central, southern, and western delta are 19.2, 46.4, 37.2, and $35.8 \mathrm{ppm}$, respectively (Table 2).

Interpretation of the diamondoid hydrocarbon distributions indicates that the Niger Delta oils are sourced by a type II marine source (Figure 20), similar to that of the marine shale of the North Sea Spekk Formation of Oxfordian-Ryazanian age, which was deposited during anoxic bottom water conditions, as reported by Schulz et al. (2001). The standard marine type II kerogen-sourced North Sea oil from the Oseberg field analyzed in this work also plots in the same field as the Nigerian oils analyzed (Figure 21), indicating that their source organic matter was similar. This suggests that there has not been any major contribution to the Niger Delta oils from either a mixed type II and III or type III organic matter source, in contrast to that indicated by the previous interpretations of other geochemical parameters.

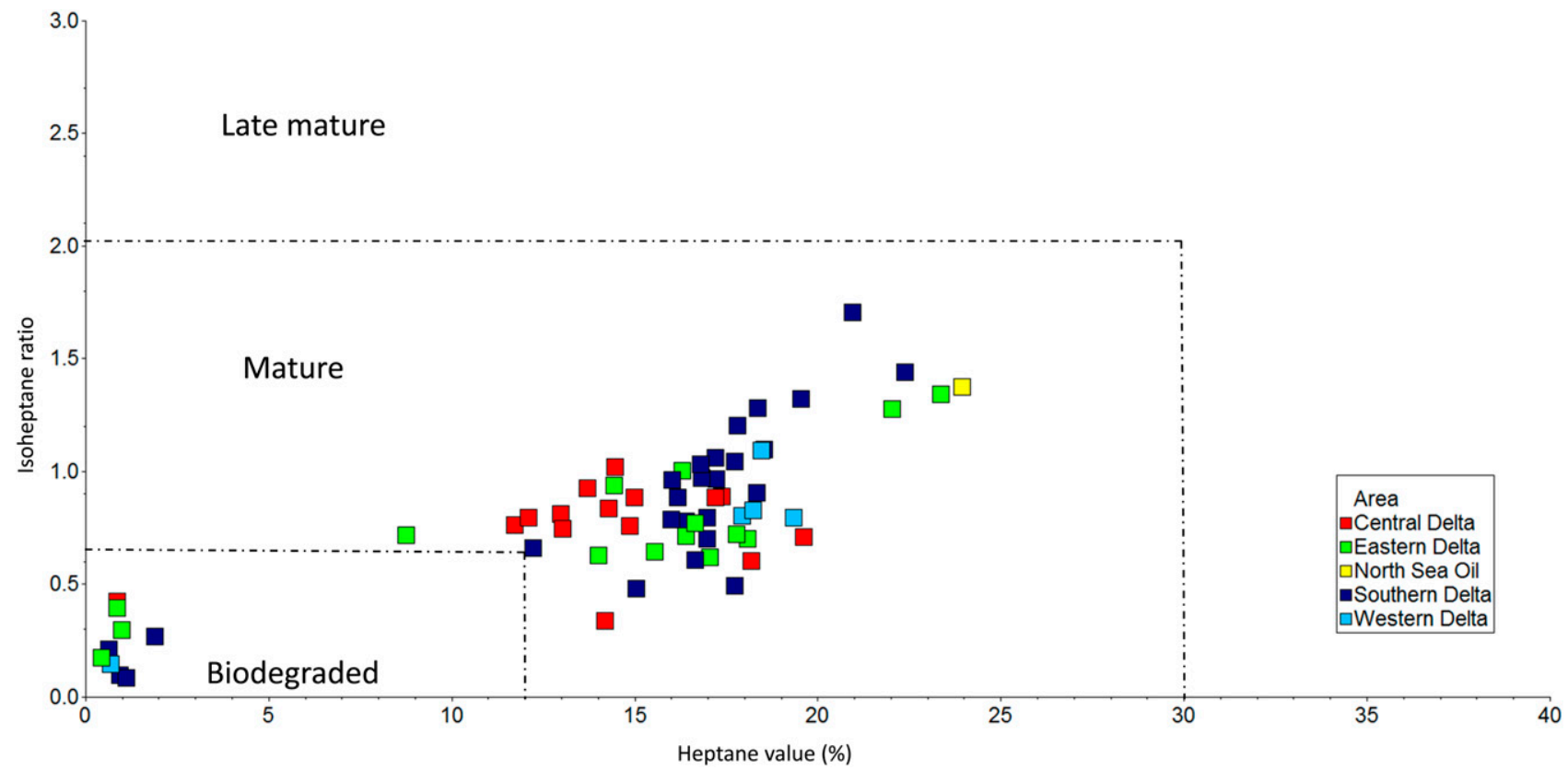

Figure 16. Variation in maturity of Niger Delta oil samples based on the isoheptane ratio and the heptane ratio (modified after Thompson, 1983). The dotted lines indicate the areas for biodegraded, mature, and late mature. 


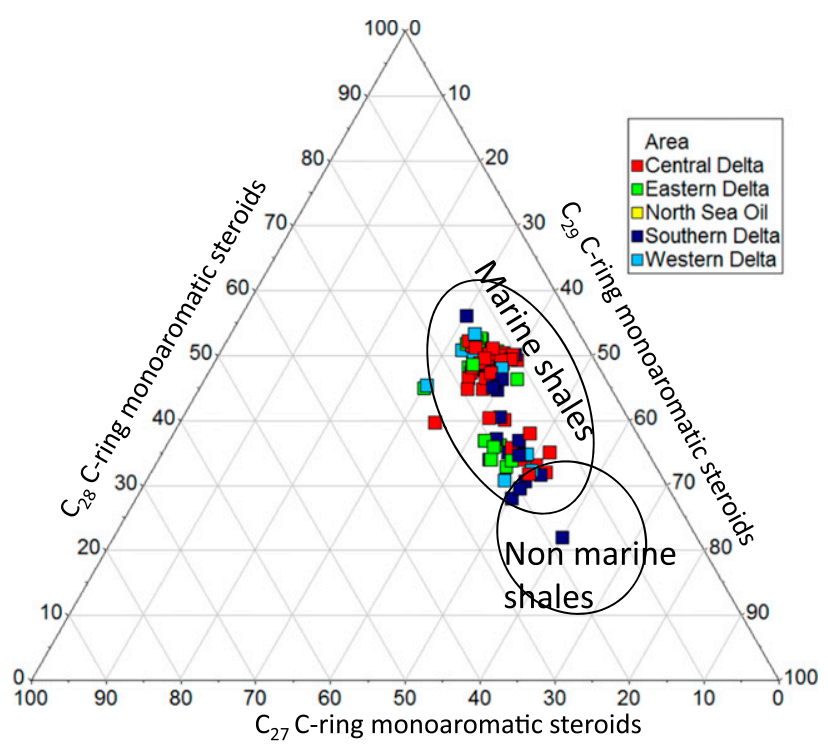

Figure 17. Source environment of deposition ternary plot of $\mathrm{C}_{27}, \mathrm{C}_{28}$, and $\mathrm{C}_{29}$ C-ring monoaromatic steroids showing the Niger Delta oil samples are sourced from marine shale (modified after Moldowan et al., 1985).

The thermal maturity assessment of highly mature oils can be difficult because they are commonly devoid of the commonly used biomarkers (Dahl et al., 1999). Although absolute concentrations of adamantanes in these oils were not used because of possible evaporation losses (cf. Y. Li et al., 2014; Chakhmakhchev et al., 2017), most oil samples (apart from nine samples) have not suffered evaporative loss based on the alteration parameters from Thompson (1987) (toluene/n-heptane [aromaticity ratio] of 0.02-1.3 and n-heptane/methylcyclohexane [paraffinity ratio] of $0.4-0.9$ ).

A crossplot of the diamondoid maturity parameters 100(1-methyadamantane/1- + 2-methyladamantane) (MAI) against 100(4-methyldiamantane/ 4- + 1- + 3-methyldiamantane) (MDI) (e.g., Chen et al., 1996; Nasir and Fazeelat, 2013) shows that the Niger Delta oil samples are in the late oil window and early gas window, with $R_{o e}$ values of 1.1-1.6 (Figure 22). In addition, other diamondoidbased thermal maturity parameters support the interpretation that these oil samples are of high thermal maturity. The results from dimethyladamantane index (i.e., 1,3-DMA/[1,2-DMA + 1,3DMA]) between 0.42 and 0.71 , with an average of 0.66 (i.e., $R_{o e}$ values of 1.2-1.9), and ethyladamantane index (i.e., 2-EA/[1-EA + 2-EA]) between 0.65 and 0.82 , with an average of 0.72 (i.e., $R_{o e}$ values of 1.3-1.8), suggest that the oils are of late oil window to late gas window maturity (e.g., Fang et al., 2013).

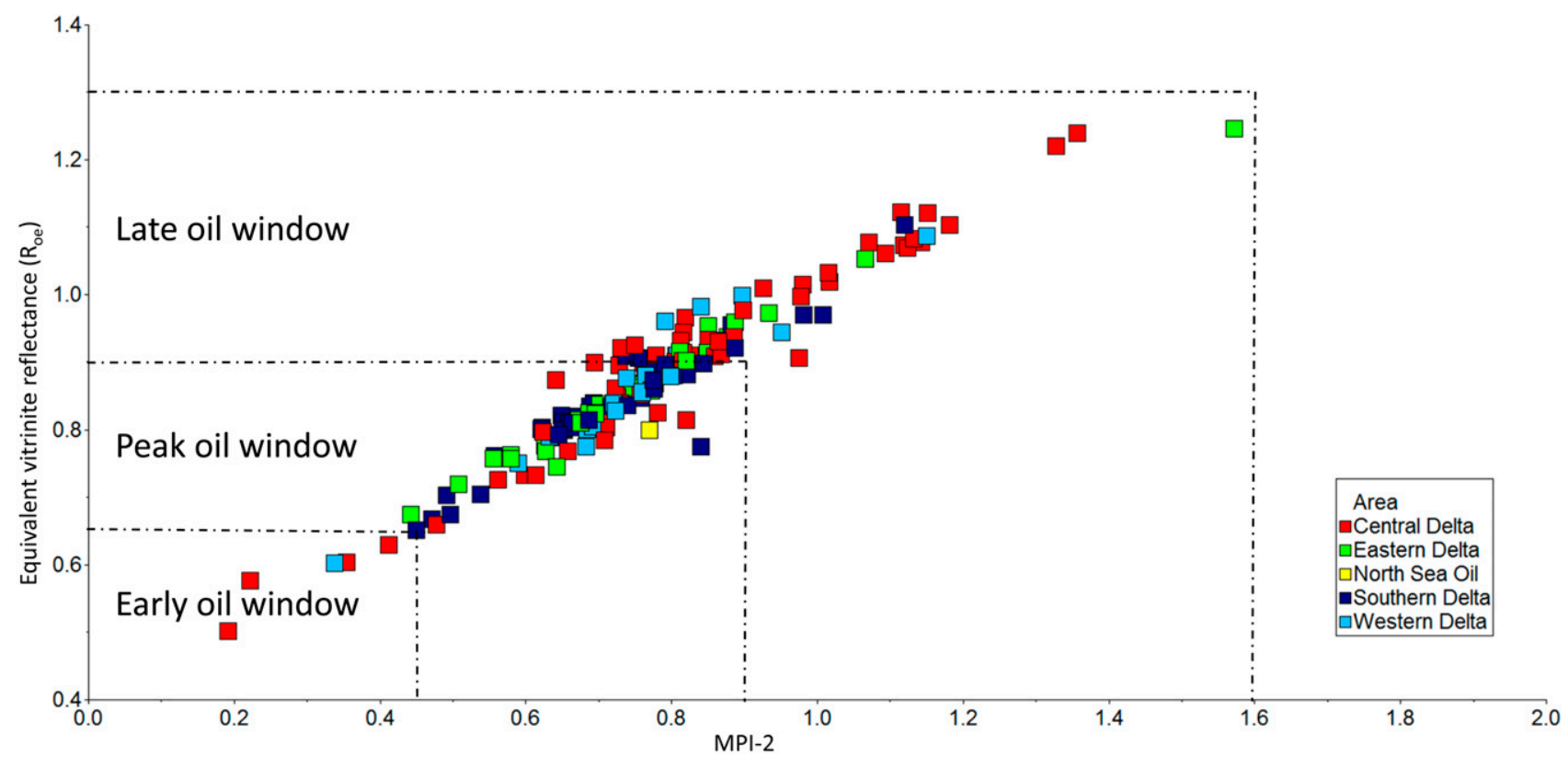

Figure 18. Plot of equivalent vitrinite reflectance against methylphenanthrene index-2 (MPI-2) showing that the Niger Delta oil samples are in the peak to late oil window maturity range. MPI-1 is defined as 1.5(2-methylphenanthrene + 3-methylphenanthrene)/(phenanthrene + 1methylphenanthrene + 9-methylphenanthrene), and MPI-2 is defined as 3(2-methylphenanthrene)/(phenanthrene + 1-methylphenanthrene + 9-methylphenanthrene). MPI-1 is a variable in the calculation of equivalent vitrinite reflectance $(\mathrm{Rc})=(0.6[\mathrm{MPI}-1]+0.4)$ after Radke et al. $(1986)$. 


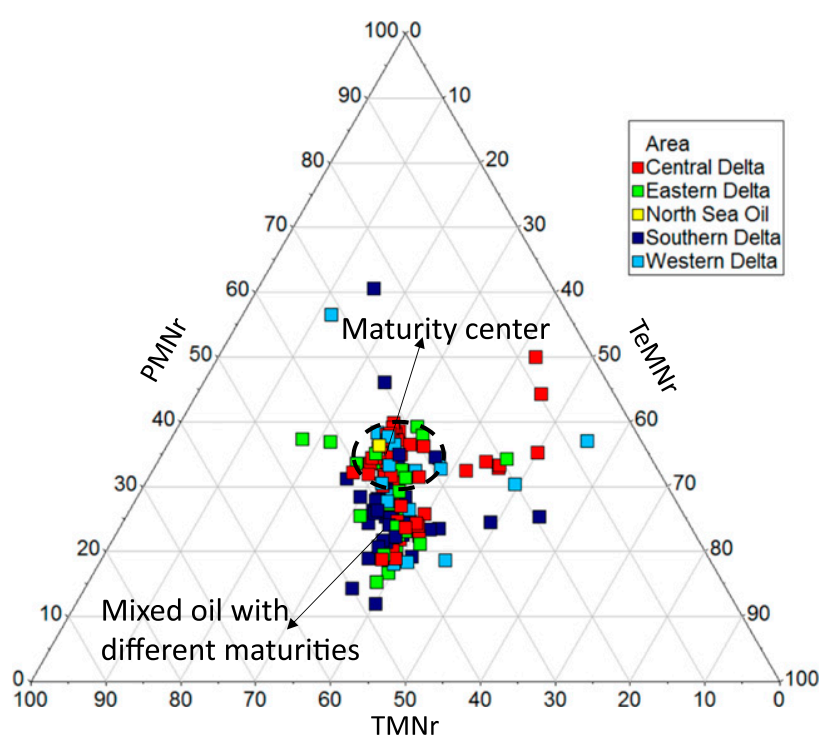

Figure 19. Ternary plot of 1,3,7-trimethylnapthalene/1,3,7$+1,2,5,7$-trimethylnapthalene (trimethylnaphthalene ratio [TMNr]), 1,3,6,7-tetramethynapthalene/1,3,6,7- + 1,2,5,6- + 1,2,3,6-tetramethylnaphthalanes (tetramethylnaphthalene ratio [TeMNr]), and 1,2,4,6,7-pentamethylnaphthalane/1,2,4,6,7+ 1,2,3,5-6-pentamethylnaphthalane (pentamethylnaphthalene ratio [PMNr]). Showing most Niger Delta oil samples plotting outside the maturity center (indicated by the dashed circle), which indicates mixing of oils with different maturities, or with indigenous organic matter or biodegradation effects (modified after van Aarssen et al., 1999).

However, it has been noted that there is a possible reversal in MDI values above $2.0 \% R_{o e}(\mathrm{~J} . \mathrm{Li}$ et al., 2000); therefore, these maturity estimates may be conservative. These $R_{o e}$ values of the Niger Delta oils are much higher than the North Sea oil (Figure 22); thus, maturity calculations based on diamondoids indicate that there has been a highly mature oil charge in the delta, with maturities far greater than those calculated from other compound class (e.g., gasoline-range hydrocarbons, normal alkanes, and biomarkers).

\section{POTENTIAL MIXING RATIOS OF THE MULTIPLE SOURCED HYDROCARBONS IN THE OILS}

The different thermal maturity and source indications based on the different hydrocarbon compound class results of these Niger Delta Basin oils indicate that they are mixtures of different thermal maturity fluids from different sources.
Thermal maturity parameters from sterane and hopane biomarkers indicate that the Niger Delta Basin oil samples are early mature, but the gasoline-range hydrocarbons show that the oils are mature; furthermore, the aromatic thermal maturity parameters give contradictory results indicating that the samples are in the peak to late oil window. The diamondoid hydrocarbons indicate that the oils are in the late oil window to late gas window. The kerogen type and source depositional environment interpretations also varied based on different compound classes. In contrast, the North Sea oil analyzed showed consistent source and maturity interpretations no matter which hydrocarbon components were analyzed. These results indicate that the analyzed Niger Delta oils were derived from a mixture of petroleum sources.

A plot of stigmastane $\left(\mathrm{C}_{29} 5 \alpha(\mathrm{H}), 14 \alpha(\mathrm{H}), 17 \alpha(\mathrm{H})-\right.$ 20R stigmastane sterane) against $3+4 \mathrm{MD}$ concentrations (Figure 23) indicates that most of the oils in the basin are mixtures of thermally cracked highmaturity oils and uncracked lower-maturity oils (cf. Dahl et al., 1999; Moldowan et al., 2015). No pure mature end-member oil samples exist that are not mixed, cracked, biodegraded, or fractionated. To account for possible paleo-biodegradation (e.g., potentially doubling the concentration of diamondoids

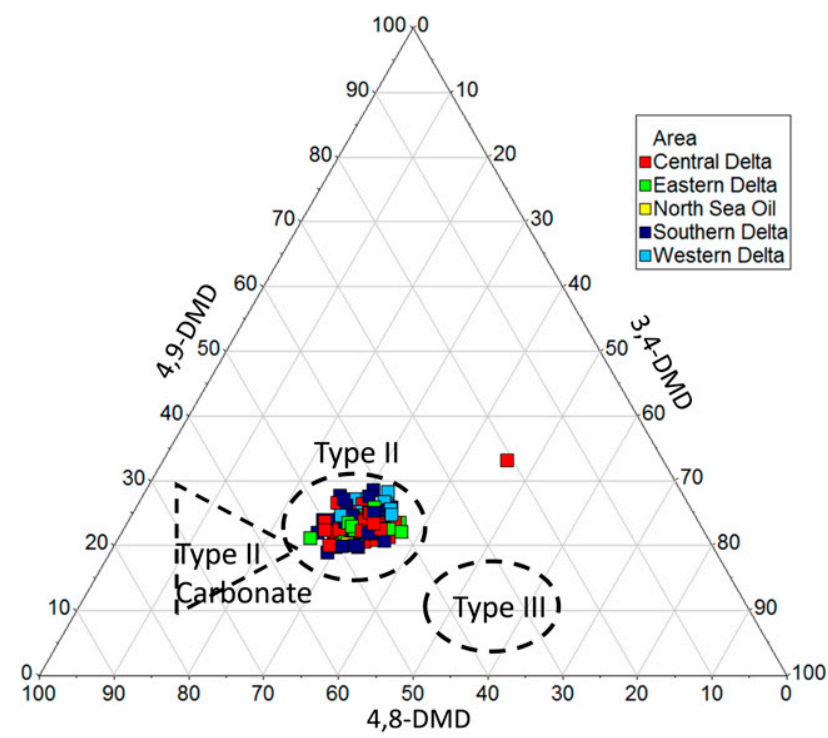

Figure 20. Ternary plot of the percentage distribution of 3,4-dimethydiamantanes (3,4-DMD), 4,8-DMD, and 4,9-DMD in the Niger Delta oil samples showing that they were sourced from type II organic matter (modified after Schulz et al., 2001). Dashed triangle and oval shapes indicate fields where different organic matter/kerogen types plot. 


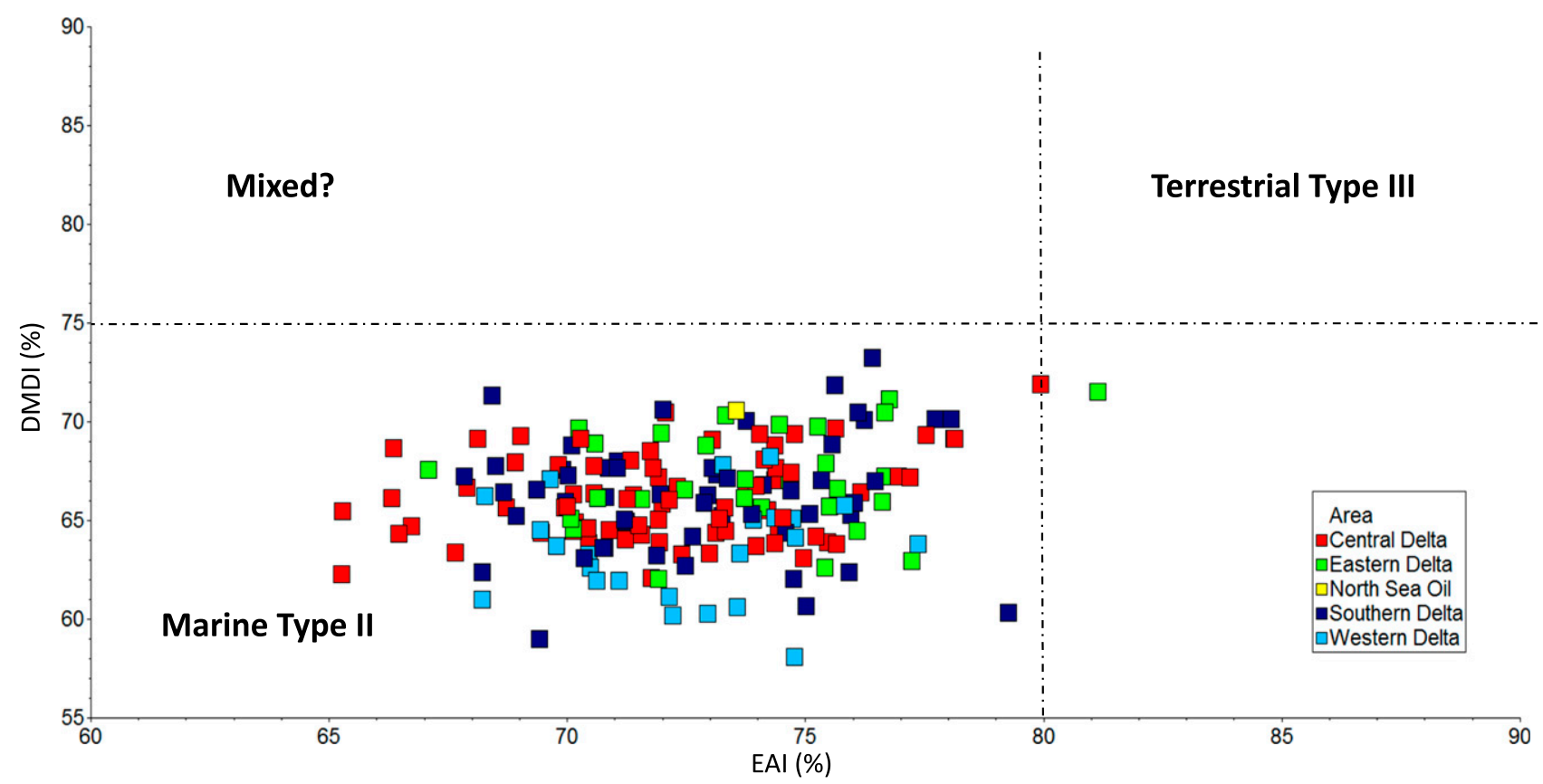

Figure 21. Diamondoid organic facies parameter plot of the Niger Delta oil samples indicating that the oil was from a type II marine source facies similar to that of the North Sea oil (after Schulz et al., 2001). DMDI $(\%)=100 \times 3,4$-dimethyldiamantane/(3,4- + 4,9-) dimethyldiamantane; EAI $(\%)=100 \times 2$-ethyladamantane/(2- + 1-) ethyladamantane.

in oil at a severe biodegradation level), the diamondoid baseline concentration for uncracked oils was assumed to be $10 \mathrm{ppm}$ for these mixture estimations instead of 5 ppm or lower, which is normally assumed as a baseline value (Dahl et al., 1999; Wei et al., 2007;
Azevedo et al., 2008; de Araujo et al., 2012; El Diasty and Moldowan, 2013). However, the stigmastane concentrations can be affected by variations in the thermal maturity of the oil, migration contamination (biomarkers picked up by the oil during migration

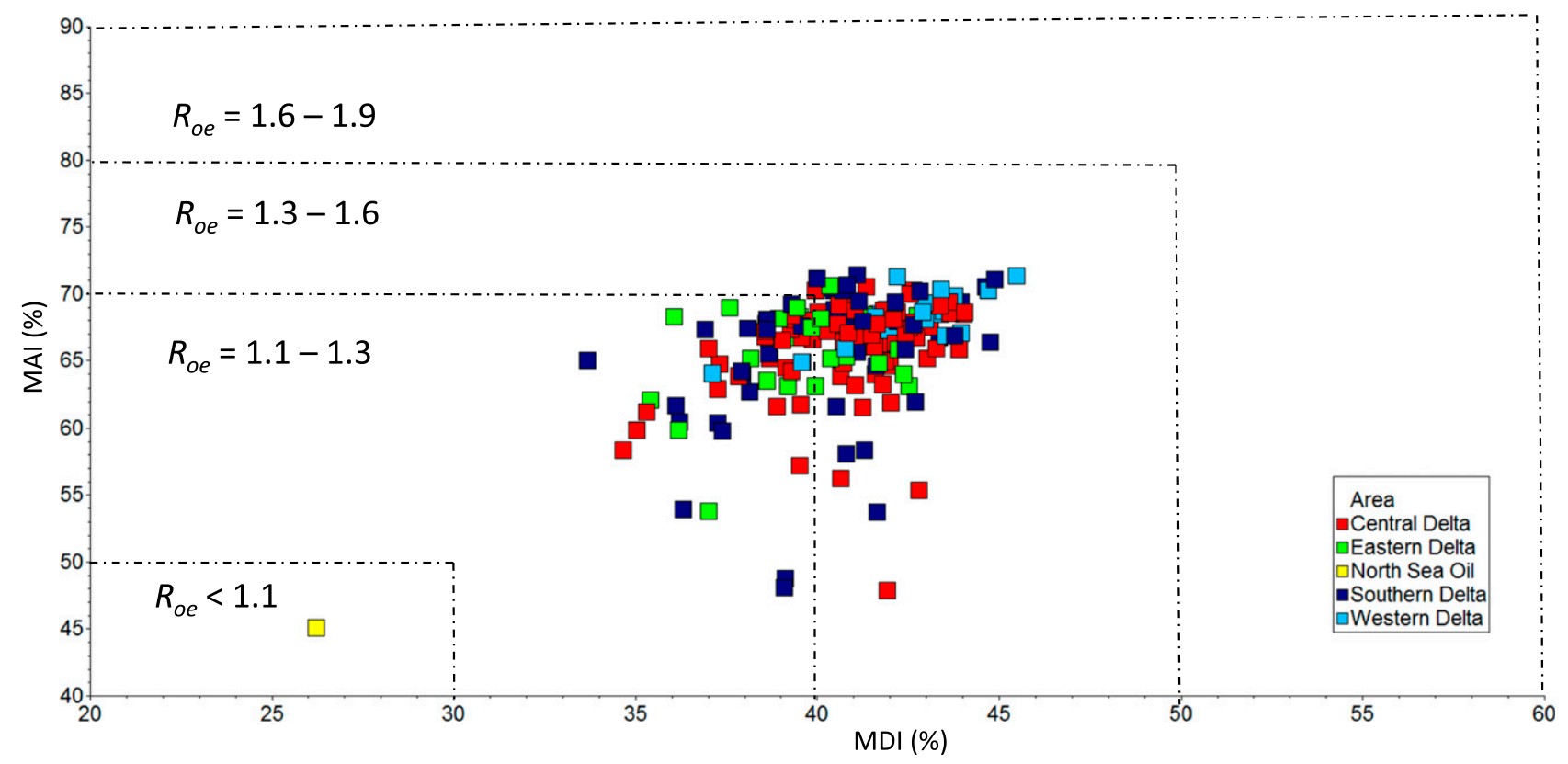

Figure 22. Diamondoid maturity parameters plot showing very high maturity in the Niger Delta oils (equivalent vitrinite reflectance $\left[R_{o e}\right]$ of 1.1\%-1.6\%). Note the lower maturity of the North Sea oil when compared to the Niger Delta oils (modified after Chen et al., 1996). MAI $(\%)=100 \times 1$-methyadamantane/(1- + 2-) methyladamantane; MDI (\%) = $100 \times 4$-methyldiamantane/(4- + 1- + 3-) methyldiamantane. 


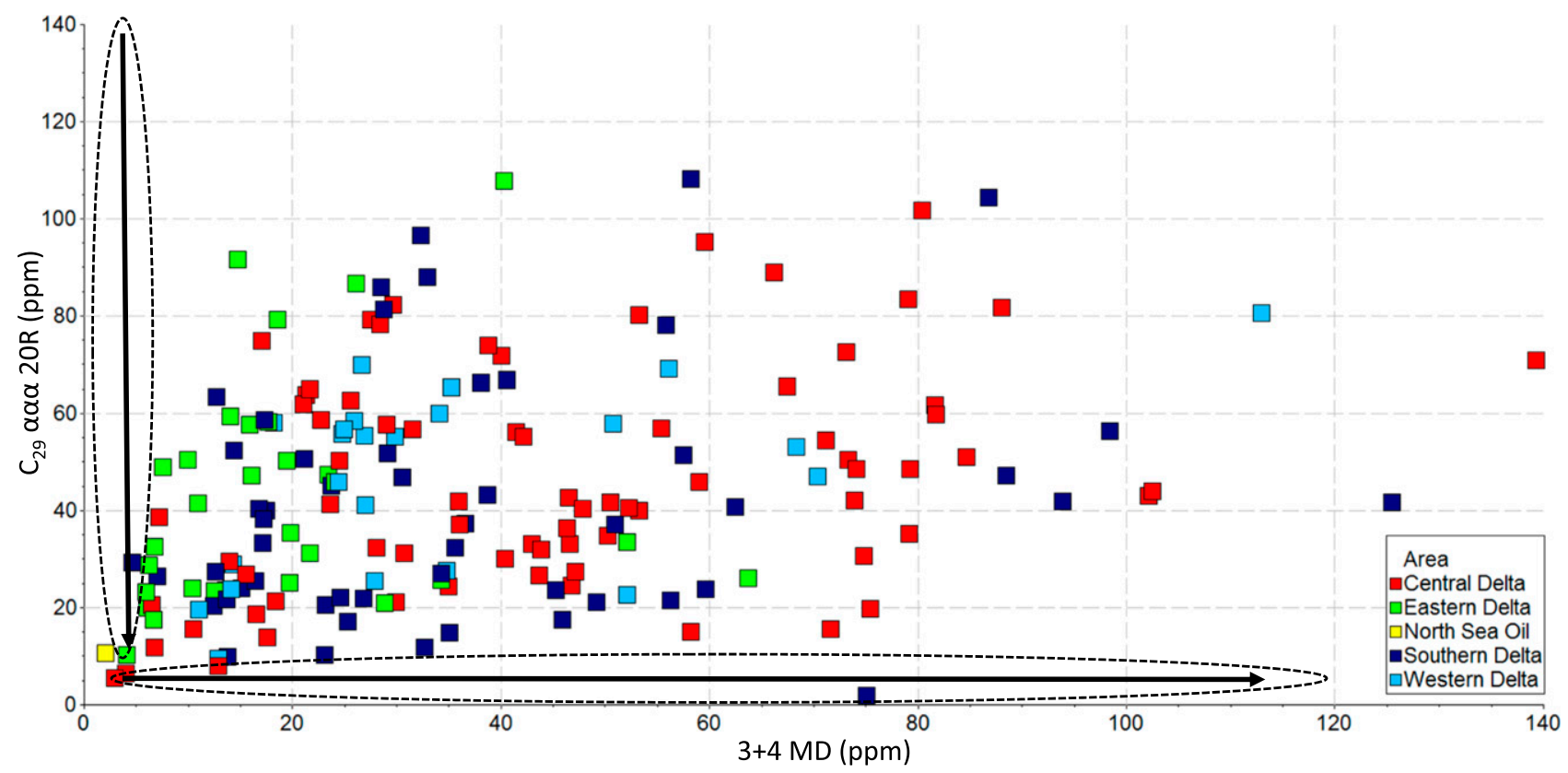

Figure 23. Plot of $\mathrm{C}_{29} \alpha \alpha \alpha$ 20R stigmastane against 3-methyldiamantane +4 -methyldiamantane $(3+4 \mathrm{MD})$ concentrations (modified after He et al., 2012), indicating thermal cracking and mixing in Niger Delta oils. Oils should plot within the oval lines based on maturity and cracking alone and without mixing of high-maturity oils and low-maturity ones. The arrows indicate maturity and cracking trends in samples that are not mixed.

through less mature organic-rich rocks and in reservoir), and biodegradation, as well as mixing. Migration contamination is known to be common in PaleogeneNeogene deltaic petroleum systems like the Niger Delta (Ukpabio et al., 1994; J. A. Curiale, 2002).
Therefore, quantitative oil mixing estimates based on such biomarkers can be difficult when one or more of these processes have occurred.

Using some assumptions about the likely diamondoid concentrations in the end-member cracked

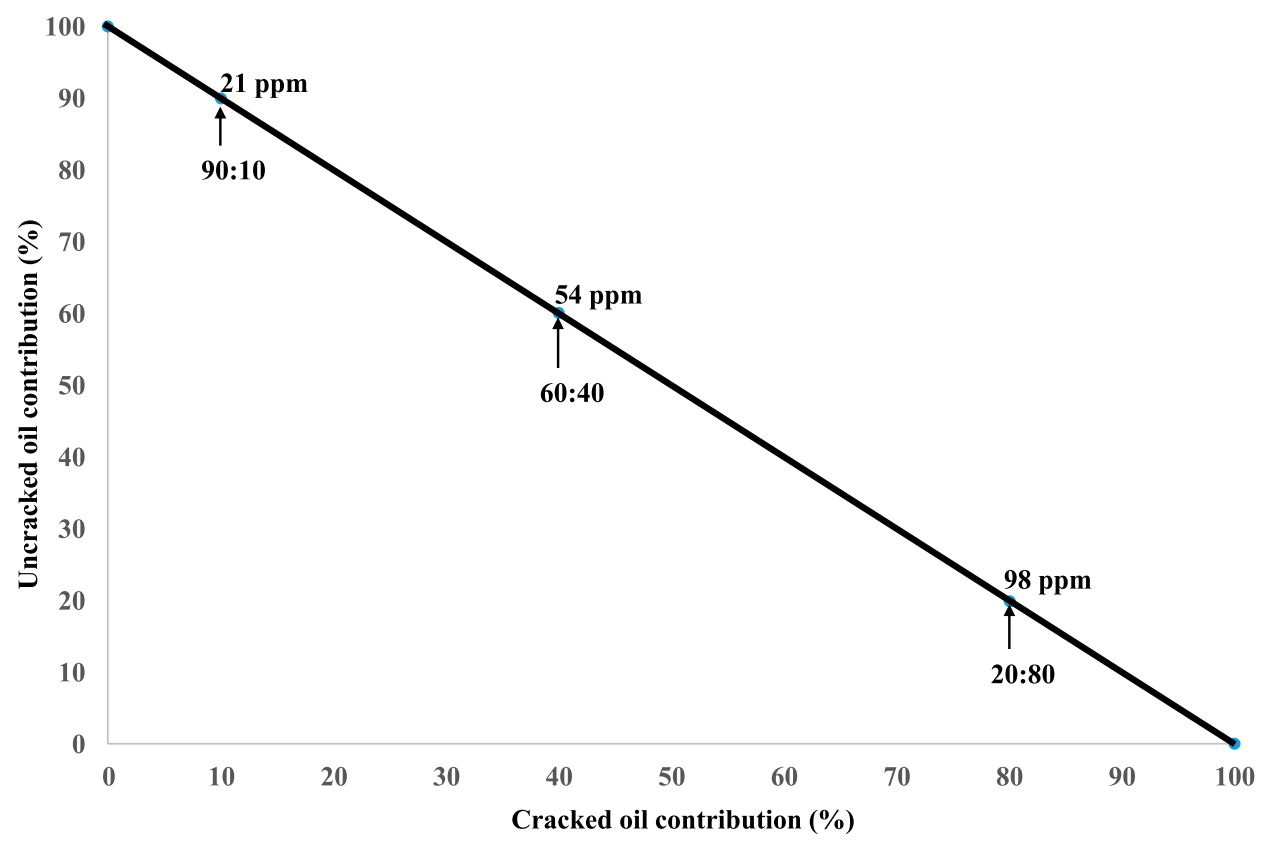

Figure 24. Simple mixing line showing the percentage contributions of cracked and uncracked oils to oil mixtures based on diamondoid 3-methyldiamantane + 4-methyldiamantane concentrations, assuming the cracked oil contained $120 \mathrm{ppm}$ and the uncracked oil $10 \mathrm{ppm}$ of diamondoids. 
(120 ppm) and uncracked (10 ppm) oils, estimations can be made about the compositions of these mixtures. For example, an oil with a diamondoid concentration of $21 \mathrm{ppm}$ must be a mixture of $90 \%$ uncracked oil and $10 \%$ cracked oil (Figure 24) based on a simple mixing line calculation $((90 \% \times 10)+(10 \% \times 120))$. However, the diamondoid concentrations in the oils could have been increased significantly if the cracked oil was heavily biodegraded prior to or after mixing. Biodegradation to level 5, as described by Peters and Moldowan (1991), may mean that approximately $50 \%$ of the oil could have either been degraded or lost (Head et al., 2003). In that case, because diamondoids are particularly recalcitrant to biodegradation, their concentrations could have doubled, which would have an impact on the simple mixing line estimates (e.g., Figure 24). This is shown in Figure 25, in which the whole oil chromatogram of a sample with the highest $3+4 \mathrm{MD}$ concentration (139 ppm) indicates significant mixing with the early charge(s) biodegraded, whereas the later charge(s) has the light ends preserved (Figure 25).

In addition, nine oil samples have elevated toluene/ n-heptane (aromaticity ratio) values (i.e., 1.61-9.03), indicating they have been fractionated (e.g., Thompson, 1987). These nine samples have diamondoid $(3+4$ MD) concentrations between 6.5 and 79.5 ppm (average $31 \mathrm{ppm}$ ). The two most fractionated samples (based on the ratios proposed in Thompson, 1987) have diamondoid concentrations of 6.5 and $6.6 \mathrm{ppm}$. The light ends of these fractionated oil samples must have been depleted, thus leading to a reduction in the concentration of diamondoids in these samples. Therefore, nine fractionated oil

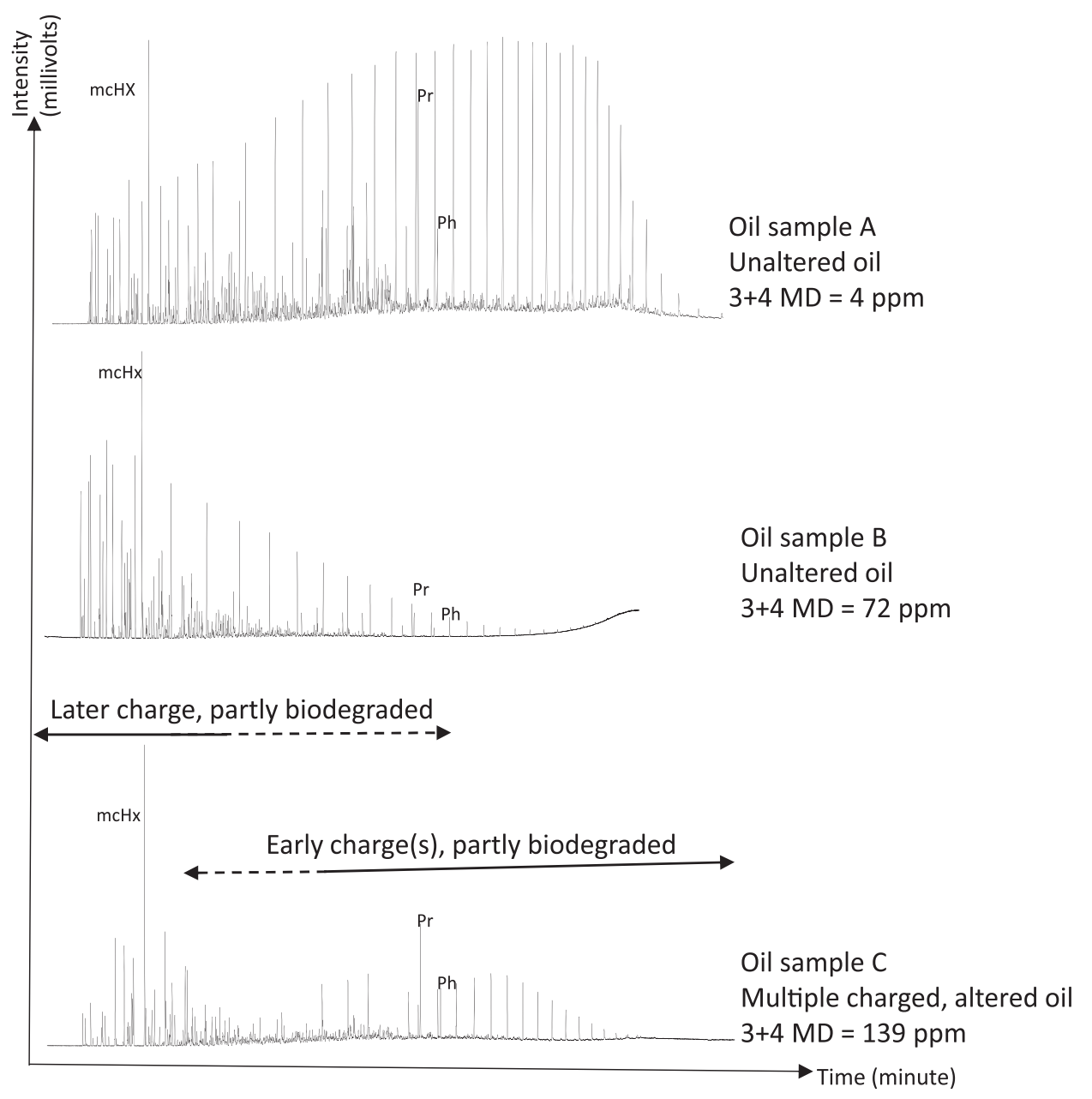

Figure 25. Whole oil gas chromatograms of selected oil samples showing different trends and diamondoid concentrations. Note evidence of multiple charge in oil sample $\mathrm{C} .3+4 \mathrm{MD}=3$-methyldiamantane + 4-methyldiamantane; $\mathrm{mcHx}=$ methylcyclohexane; $\mathrm{Ph}=$ phytane; $\operatorname{Pr}=$ pristane. 


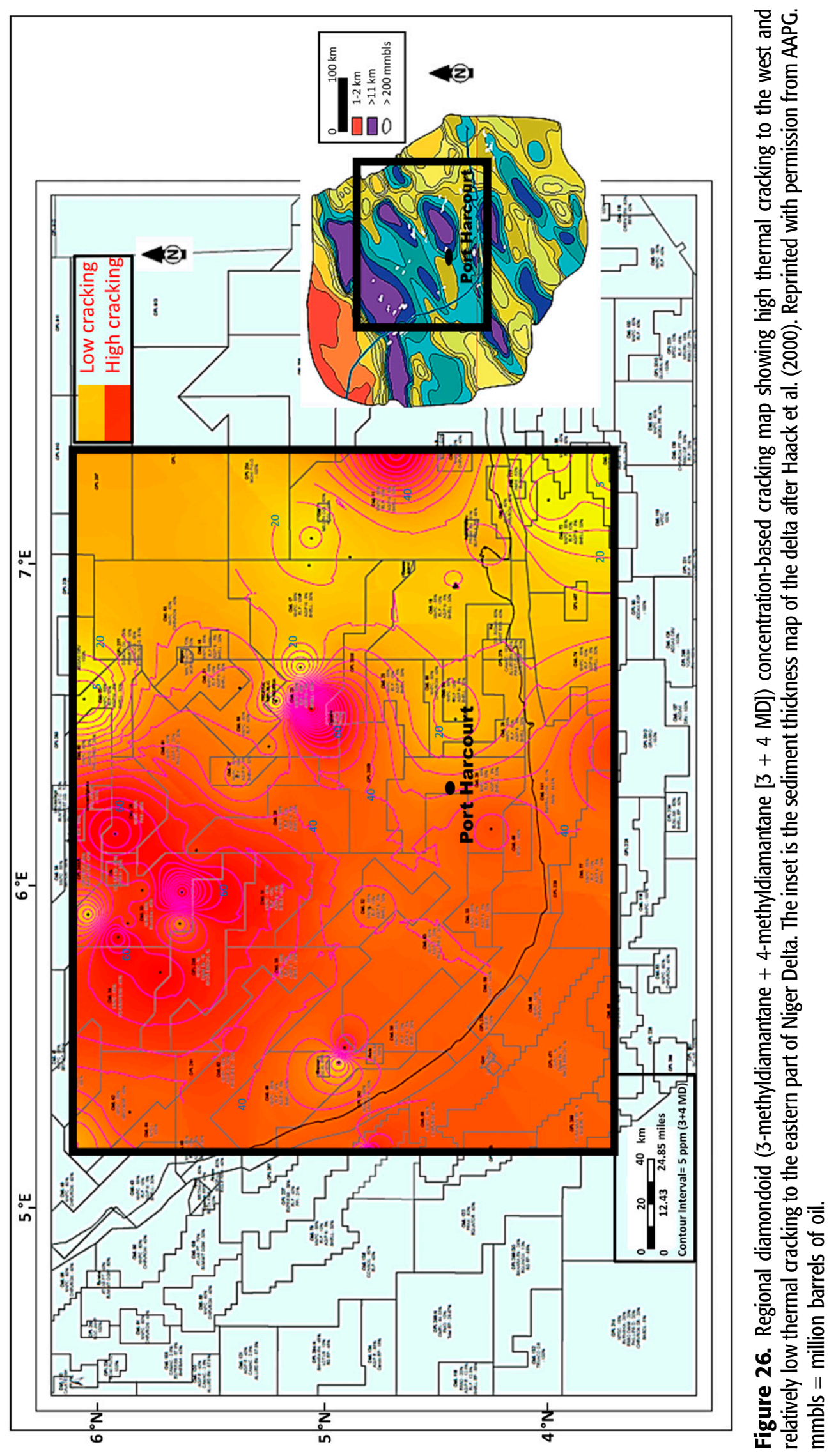

ESEGBUE Et AL. 
samples were not considered during the overall interpretation.

A thermal cracking map based on the concentrations of $3+4$ MDs shows that the delta can be divided into two broad areas (Figure 26). The western delta area shows a regional trend of highly cracked oil. The eastern delta area displays less oil cracking. This regional cracking pattern bears a striking similarity to the combined gravity and magnetic variation basement structure map produced by Haack et al. (2000), which shows that most parts of the western delta have more than $11 \mathrm{~km}$ of sediment, whereas those of the eastern delta are less thick. The sediment thickness (and thus source rock burial depth) can be inferred as a major controlling factor on the thermal maturity of the oil samples from the Niger Delta Basin. In addition, as mentioned by Haack et al. (2000), because of the complexity and northwestsoutheast regional structures, long-distance lateral migration of oil and gas updip to the northeast across major faults is unlikely. Migration in the basin is most likely predominantly vertical. This view by Haack et al. (2000) and previously proposed by Stacher (1995) is strongly supported by the diamondoidbased thermal cracking map in this study (Figure 26). Thus, a new model of the Niger Delta Basin, which accounts for the elevated diamondoid hydrocarbon concentrations found in the oils from this basin, can be illustrated as shown in Figure 27.

\section{CONCLUSIONS}

Differing geochemical interpretations of the origins of the Niger Delta oil samples in this study can be arrived at based on different hydrocarbon component parts of oil. This is in contrast to the result of a North Sea oil analyzed concurrently that yields quite consistent source, depositional environment, and thermal maturity interpretations using hydrocarbon components. This situation has arisen because of the complexity of the Niger Delta petroleum system(s).

Thermal maturity measurements from the hydrocarbon fraction analyses indicated that there were at least two possible charges in the Niger Delta Basin oils studied. These consisted of a highly mature and thermally cracked charge, possibly coming from a subdelta (deeply buried Cretaceous) source, as indicated by the diamondoid hydrocarbon analyses, and another from a peak mature charge from a source that had not been buried as deeply as the highly mature charge, as indicated by the results from the gasolinerange and aromatic hydrocarbons. The highly mature early charge was sourced from a type II kerogen deposited in a marine environment and was of late oil to late gas window maturity. The peak oil window maturity charge appears to have been sourced from shales containing primarily type II kerogen deposited in marine environment with variable proportions of terrigenous input depending on proximity to land at the time

NNE

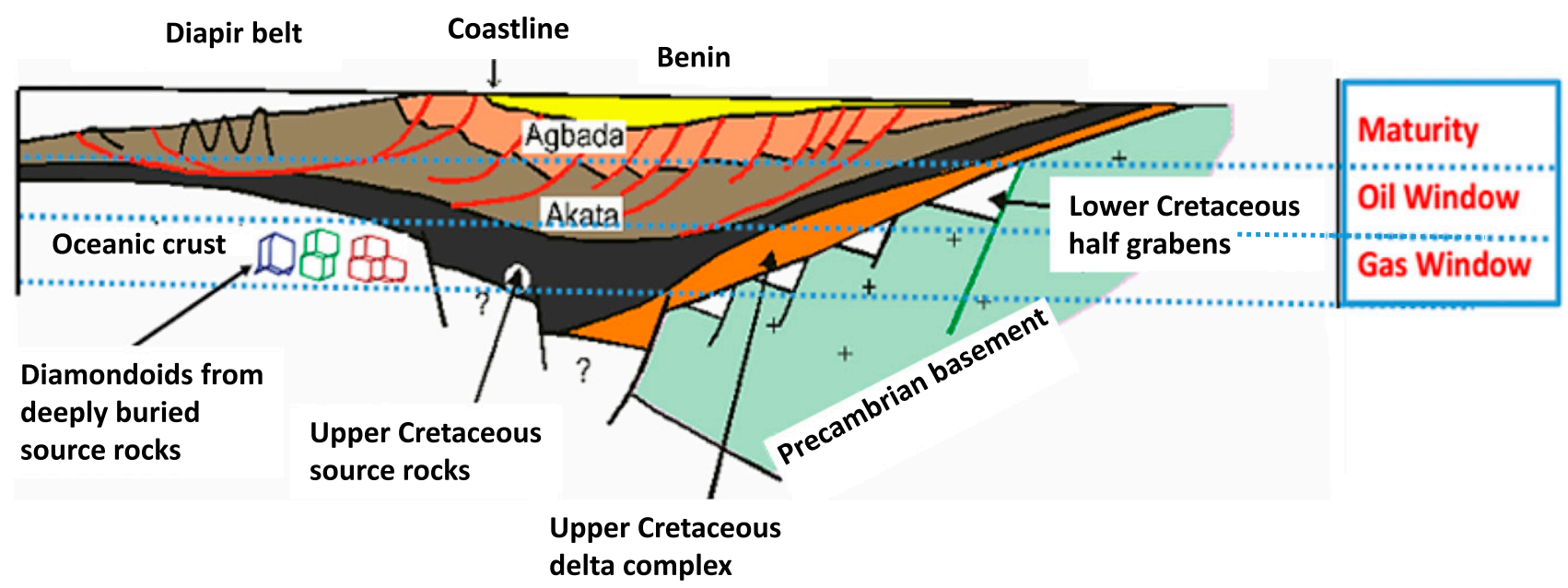

Figure 27. A cross section of the Niger Delta Basin (north-northeast to south-southwest) showing the different formations (modified after Thomas, 1995 and used with permission from Oil \& Gas Journal) and their proposed regional thermal maturities relating to oil and gas generation. Note that localized thermal gradient hot spots were not considered. Red lines are growth faults, and plus signs indicate the Precambrian basement. 
of deposition (i.e., mixed type II and III). The central and southern delta areas display the highest terrigenous inputs compared to the other parts of the delta.

It is possible to conclude that the highly mature charge was generated by a type II subdelta source that is of regional extent and was responsible for a high proportion of the oil in the Niger Delta that has migrated into the Paleogene-Neogene reservoirs of the Agbada Formation. The mature charge must have been from the thick Akata Formation that was deposited during the rapid prograding sedimentation in the Niger Delta and possibly source rocks at the base of the Agbada Formation.

Therefore, this work indicates that the PaleogeneNeogene reservoired hydrocarbons in Niger Delta Basin are derived from multiple source rocks, and the highly mature charge must have been biomarker depleted, as indicated by the elevated diamondoid concentrations, which reveal the high thermal cracking.

\section{APPENDIX: METHODS}

\section{Laboratory Analyses}

\section{Hydrocarbon Separation}

Aliquots ( $~ 50 \mathrm{mg}$ or less) of oils were separated using the SPE method described by Bennett et al. (1996) to provide a total hydrocarbon fraction, which was then further separated by silver nitrate impregnated silica gel SPE chromatography into saturated and aromatic fractions (Bennett and Larter, 2000). One Nigerian oil sample was analyzed with each batch of 20 oil analyses for reproducibility and analytical quality control purposes. An NPD geochemical standard NSO-1 aliquot no. 11.27 from the Oseberg field was also analyzed to assess the reliability of the results obtained.

\section{Gas Chromatography}

The GC-flame ionization detector (FID) analysis was performed on a Hewlett-Packard 5890 Series II GC with an injector at $280^{\circ} \mathrm{C}$ and FID at $310^{\circ} \mathrm{C}$. The sample $(1 \mu \mathrm{l})$ was injected by an Hewlett-Packard 7673 autosampler in splitless mode. The oven temperature ramp program used was from $50^{\circ} \mathrm{C}$ (held for $2 \mathrm{~min}$ ) to $300^{\circ} \mathrm{C}$ at $5^{\circ} \mathrm{C} / \mathrm{min}$. and held at the final temperature $\left(300^{\circ} \mathrm{C}\right)$ for $20 \mathrm{~min}$, with a total run time of $74 \mathrm{~min}$. Hydrogen was used as the carrier gas, with a flow rate of $1 \mathrm{ml} / \mathrm{min}$, inlet pressure of $50 \mathrm{kPa}$, and split set at $30 \mathrm{ml} / \mathrm{min}$. Separation was performed on a fused silica capillary column $(30-\mathrm{m} \times 0.25-\mathrm{mm}$ inner diameter [i.d.]) coated with $0.25 \mu \mathrm{m} 5 \%$ phenylmethylpolysiloxane (HP-5) phase.

\section{Gas Chromatography-Mass Spectrometry}

The GCMS analysis of the aliphatic and aromatic hydrocarbon fractions was performed on an Agilent 7890A GC fitted with a split or splitless injector (at $280^{\circ} \mathrm{C}$ ) linked to an Agilent 5975C mass selective detector (electron voltage: $70 \mathrm{eV}$; source temperature: $230^{\circ} \mathrm{C}$; quadrupole temperature: $150^{\circ} \mathrm{C}$; multiplier voltage: $1800 \mathrm{v}$; interface temperature: $310^{\circ} \mathrm{C}$ ). Data acquisition and processing used Agilent ChemStation software. Selected samples were analyzed in full-scan mode (50-600 atomic mass units/s), but all samples were analyzed in selected ion monitoring mode (30 ions, 0.7 counts per second, $35 \mathrm{~ms}$ dwell) for greater sensitivity. The sample $(1 \mu \mathrm{l})$ diluted in either hexane (aliphatic fraction) or dichloromethane (aromatic fraction) was injected using an Agilent 7683B autosampler; the split opened $1 \mathrm{~min}$ after the solvent peak had passed and the GC temperature program and data acquisition commenced. Separation was performed on an Agilent fused silica capillary column $(30-\mathrm{m} \times 0.25-\mathrm{mm}$ i.d.) coated with 0.25 $\mu \mathrm{m}$ HP-5 phase. The GC was temperature programmed from $50^{\circ} \mathrm{C}$ to $310^{\circ} \mathrm{C}$ at $5^{\circ} \mathrm{C} / \mathrm{min}$ and held at final temperature for $10 \mathrm{~min}$ with helium as the carrier gas (flow rate of $1 \mathrm{ml} / \mathrm{min}$, initial inlet pressure of $50 \mathrm{kPa}$, split at $30 \mathrm{ml} / \mathrm{min}$ ).

The determination of concentration of individual compounds was based on comparing the peak areas of the compounds to be measured with those of a known concentration of an added internal standard (n-heptadecylcyclohexane). The diamondoid and stigmastane analyte compound concentrations were then corrected using response factors from the analysis of a condensate sample of known diamondoid concentrations and $5 \alpha(\mathrm{H})$ cholestane standard, respectively.

\section{Gas Chromatography-Tandem Mass Spectrometry}

Spectrometry analysis of aliphatic compounds was performed on a Varian CP-3800 GC with a split/splitless injector $\left(280^{\circ} \mathrm{C}\right)$ linked to a Varian 1200 triple quadrupole mass spectrometer (electron voltage: $70 \mathrm{eV}$, filament current: $175 \mu \mathrm{A}$, source temperature: $230^{\circ} \mathrm{C}$, quadrupole temperature: $40^{\circ} \mathrm{C}$; multiplier voltage: $1300 \mathrm{v}$; interface temperature: $300^{\circ} \mathrm{C}$ ). Varian software controlled the acquisition. Data were acquired in tandem mass spectrometry mode, in which up to 10 parent-to-daughter transitions could be monitored using argon as collision gas at a pressure of 2 millitorr in Q2, with collision energy of $-10 \mathrm{eV}$.

The sample $(1 \mu l)$ in dichloromethane was injected using a Varian CP-8400 autosampler, and the split opened after 1 min. After the solvent peak had passed, the GC temperature program and data acquisition commenced and separation was performed on a fused silica capillary column $(30-\mathrm{m} \times 0.25$ $\mathrm{mm}$ i.d.) coated with $0.25 \mu \mathrm{m} \mathrm{HP}-5$, with helium as the carrier gas (flow $1 \mathrm{ml} / \mathrm{min}$ initial pressure of $50 \mathrm{kPa}$, split at 30 $\mathrm{ml} / \mathrm{min}$ ). The GC was temperature programmed from $50^{\circ} \mathrm{C}$ to $310^{\circ} \mathrm{C}$ at $5^{\circ} \mathrm{C} / \mathrm{min}$ and held at final temperature for $10 \mathrm{~min}$.

\section{REFERENCES CITED}

Akinlua, A., and T. R. Ajayi, 2009, Geochemical characterization of Central Niger Delta oils: Petroleum Geology, v. 32, no. 4, p. 373-382, doi:10.1111/j.1747-5457.2009 $.00456 . x$. 
Akinlua, A., T. R. Ajayi, and B. B. Adeleke, 2006, Niger Delta oil geochemistry: Insight from light hydrocarbons: Journal of Petroleum Science and Engineering, v. 50, no. 3-4, p. 308-314, doi:10.1016/j.petrol.2005.12.003.

Akinlua, A., and N. Torto, 2011, Geochemical evaluation of Niger Delta sedimentary organic rocks: A new insight: Earth Science, v. 100, p. 1401-1411, doi:10.1007/s00531010-0544-z.

Alexander, R., R. I. Kagi, and G. W. Woodhouse, 1981, Geochemical correlation of Windalia oil and extracts of Winning Group (Cretaceous) potential source rocks, Barrow Subbasin, Western Australia: AAPG Bulletin, v. 65 , no. 2 , p. $235-250$.

Allen, J. R. L., 1965, Late Quaternary Niger Delta, and adjacent areas: Sedimentary environments and lithofacies: AAPG Bulletin, v. 49, no. 5, p. 547-600, doi:10.1306 /A663363A-16C0-11D7-8645000102C1865D.

Atta-Peters, D., and P. Garrey, 2014, Source rock evaluation and hydrocarbon potential in the Tano Basin, south western Ghana, West Africa: International Journal of Oil, Gas and Coal Engineering, v. 2, no. 5, p. 66-77, doi:10.11648/j.ogce.20140205.11.

Avbovbo, A. A., 1978, Tertiary lithostratigraphy of Niger Delta: Geologic notes: AAPG Bulletin, v. 62, no. 2, p. 295-300.

Azevedo, D. A., J. B. Tamanqueira, J. C. M. Dias, A. P. B. Carmo, L. Landau, and F. T. T. Gonçalves, 2008, Multivariate statistical analysis of diamondoid and biomarker data from Brazilian basin oil samples: Fuel, v. 87, no. 10-11, p. 2122-2130, doi:10.1016/j.fuel.2007.11.005.

Baskin, D. K., 1997, Atomic H/C ratio of kerogen as an estimate of thermal maturity and organic matter conversion: AAPG Bulletin, v. 81, no. 9, p. 1437-1450, doi: 10.1306/3B05BB14-172A-11D7-8645000102C1865D.

Baudouy, S., and C. Legorjus, 1991, Sendji field - People's Republic of Congo, Congo Basin, in E. A. Beaumont and N. H. Foster, eds., Structural traps V. Atlas of oil and gas fields: AAPG Treatise of Petroleum Geology, p. 121-149.

Beka, F. T., and M. N. Oti, 1995, The distal offshore Niger Delta: Frontier prospects of a mature petroleum province, in M. N. Oti, and G. Postma, eds., Geology of deltas: Rotterdam, the Netherlands, August Aimé Balkema, p. 237-241.

Bellingham, P., C. Connors, R. Haworth, B. Radovich, and A. Danforth, 2014, The deepwater Niger Delta: An underexplored world-class petroleum province: GeoExPro., v. 11, p. 55-56.

Bennett, B., B. F. J. Bowler, and S. R. Larter, 1996, Determination of $\mathrm{C}_{0}-\mathrm{C}_{3}$ alkylphenols in crude oils and waters: Analytical Chemistry, v. 68, no. 20, p. 3697-3702, doi: 10.1021/ac960299x.

Bennett, B., and S. R. Larter, 2000, Quantitative separation of aliphatic and aromatic hydrocarbons using silver ionsilica solid-phase extraction: Analytical Chemistry, v. 72, no. 5, p. 1039-1044, doi:10.1021/ac9910482.

Bray, E. E., and E. D. Evans, 1961, Distribution of $n$-paraffins as a clue to the recognition of source beds: Geochimica et Cosmochimica Acta, v. 22, no. 1, p. 2-15, doi:10.1016 /0016-7037(61)90069-2.
Brownfield, M. E., and R. R. Charpentier, 2006, Geology and total petroleum systems of the West-Central Coastal Province (7203), West Africa: Reston, Virginia, US Geological Survey Bulletin 2207-B, 52 p.

Burke, K., 1972, Longshore drift, submarine canyons, and submarine fans in development of Niger delta: AAPG Bulletin, v. 56, no. 10, p. 1975-1983.

Burwood, R., J. Redfern, and M. J. Cope, 2003, Geochemical evaluation of East Sirte Basin (Libya) petroleum systems and oil provenance: Geological Society, London, Special Publications 2004, v. 207, no. 1, p. 203-240, doi:10.1144/GSL.SP.2003.207.11.

Bustin, R. M., 1988, Sedimentology and characteristics of dispersed organic matter in Tertiary Niger delta: Origin of source rocks in a deltaic environments: AAPG Bulletin, v. 72 , no. 3 , p. $277-298$.

Chakhmakhchev, A., J. Sanderson, C. Pearson, and N. Davidson, 2017, Compositional changes of diamondoid distributions caused by simulated evaporative fractionation: Organic Geochemistry, v. 113, p. 224-228, doi:10.1016 /j.orggeochem.2017.06.016.

Chen, J., J. Fu, G. Sheng, D. Liu, and J. Zhang, 1996, Diamondoid hydrocarbon ratios: Novel maturity indices for highly mature crude oils: Organic Geochemistry, v. 25, no. 3-4, p. 179-190, doi:10.1016/S0146-6380(96)00125-8.

Cornford, C., O. Christie, U. Endresen, P. Jensen, and M.-B. Myhr, 1988, Source rock and seep oil maturity in Dorset, Southern England: Organic Geochemistry, v. 13, no. 1-3, p. 399-409, doi:10.1016/0146-6380(88) 90062-9.

Corredor, F., J. H. Shaw, and F. Bilotti, 2005, Structural styles in the deep-water fold and thrust belts of the Niger Delta: AAPG Bulletin, v. 89, no. 6, p. 753-780, doi: 10.1306/02170504074.

Coward, M. P., E. G. Purdy, A. C. Ries, and D. G. Smith, 1999, The distribution of petroleum reserves in basins of the South Atlantic margins, in N. R. Cameron, R. H. Bate, and V. S. Clure, eds., The oil and gas habitats of the South Atlantic: Geological Society, London, Special Publications 1999, v. 153, p. 101-131, doi:10.1144 /GSL.SP.1999.153.01.08.

Curiale, J., R. Lin, and J. Decker, 2005, Isotopic and molecular characteristics of Miocene-reservoired oils of the Kutei Basin, Indonesia: Organic Geochemistry, v. 36, no. 3, p. 405-424, doi:10.1016/j.orggeochem.2004.09.007.

Curiale, J. A., 2002, A review of the occurrences and causes of migration-contamination in crude oil: Organic Geochemistry, v. 33, p. 1389-1400, doi:10.1016/S01466380(02)00109-2.

Curiale, J. A., and B. W. Bromley, 1996, Migration of petroleum into Vermilion 14 field, Gulf Coast, U.S.A.-Molecular evidence: Organic Geochemistry, v. 24, no. 5, p. 563-579, doi:10.1016/0146-6380(96)00033-2.

Dahl, J. E., J. M. Moldowan, K. E. Peters, G. E. Claypool, M. A. Rooney, G. E. Michael, M. R. Mello, and M. L. Kohnen, 1999, Diamondoid hydrocarbons as indicators of natural oil cracking: Nature, v. 399, p. 54-57, doi:10.1038/19953. 
de Araujo, P. L. B., G. A. Mansoori, and E. S. de Araujo, 2012, Diamondoids: Occurrence in fossil fuels, applications in petroleum exploration and fouling in petroleum production. A review paper: International Journal of Oil, Gas and Coal Technology, v. 5, no. 4, p. 316-367, doi:10.1504/IJOGCT.2012.048981.

Doust, H., and E. Omatsola, 1990, Niger delta, in J. D. Edwards and P. A. Santogrossi, eds., Divergent/passive margin basins: AAPG Memoir 48, p. 201-238.

Edwards, J. D., and P. A. Santogrossi, 1990, Summary and conclusions, in J. D. Edwards and P. A. Santogrossi, eds., Divergent/passive margin basins: AAPG Memoir 48, p. 239-248.

Eglinton, G., and R. J. Hamilton, 1967, Leaf epicuticular waxes: Science, v. 156, no. 3780, p. 1322-1335, doi: 10.1126/science.156.3780.1322.

Ejedawe, J. E., S. J. L. Coker, D. O. Lambert-Aikhionbare, K. B. Alofe, and F. O. Adoh, 1984, Evolution of oil-generative window and oil and gas occurrence in Tertiary Niger delta basin: AAPG Bulletin, v. 68, no. 11, p. 1744-1751.

Ekweozor, C. M., and E. M. Daukoru, 1984, Petroleum source-bed evaluation of the Tertiary Niger delta: Reply: AAPG Bulletin, v. 68, no. 3, p. 390-394.

Ekweozor, C. M., and E. M. Daukoru, 1994, Northern delta depobelt portion of the Akata-Agbada(!) petroleum system, Niger delta, Nigeria, in L. B. Magoon and W. G. Dow, eds., The petroleum system- From source to trap: AAPG Memoir 60, p. 599-613.

Ekweozor, C. M., J. I. Okogun, D. E. U. Ekong, and J. R. Maxwell, 1979, Preliminary organic geochemical studies of samples from the Niger delta (Nigeria) I: Analysis of crude oils for triterpanes: Chemical Geology, v. 27, no. 1-2, p. 11-28, doi:10.1016/0009-2541(79)90100-1.

Ekweozor, C. M., and N. V. Okoye, 1980, Petroleum sourcebed evaluation of the Tertiary Niger delta: AAPG Bulletin, v. 64, no. 8, p. 1251-1259.

Ekweozor, C. M., and N. Telnaes, 1990, Oleanane parameter: Verification by quantitative study of the biomarker occurrence in sediments of the Niger delta: Organic Geochemistry, v. 16, p. 401-413, doi:10.1016/0146-6380(90) 90057-7.

Ekweozor, C. M., and O. T. Udo, 1988, The oleananes: Origin, maturation and limit of occurrence in Southern Nigeria sedimentary basins: Organic Geochemistry, v. 13, no. 1-3, p. 131-140, doi:10.1016/0146-6380(88)90033-2.

El Diasty, W. S., and J. M. Moldowan, 2013, Diamondoids as indicators of thermal evolution and natural cracking of oils from the Western Desert and the Nile Delta-Egypt: Petroleum Science and Technology, v. 31, no. 7, p. 702-711, doi:10.1080/10916466.2011.654305.

Eneogwe, C., and O. Ekundayo, 2003, Geochemical correlation of crude oils in the NW Niger Delta, Nigeria: Journal of Petroleum Geology, v. 26, no. 1, p. 95-103, doi:10.1111/j.1747-5457.2003.tb00019.x.

Evamy, B. D., J. Haremboure, P. Kamerling, W. A. Knaap, F. A. Molloy, and P. H. Rowlands, 1978, Hydrocarbon habitat of Tertiary Niger delta: AAPG Bulletin, v. 62, no. 1, p. 1-39.
Fang, C., Y. Xiong, Y. Li, Y. Chen, J. Liu, H. Zhang. T. A. Adedosu, and P. Peng, 2013, The origin and evolution of adamantanes and diamantanes in petroleum: Geochimica et Cosmochimica Acta, v. 120, p. 109-120, doi:10.1016/j.gca.2013.06.027.

Frontera-Suau, R., F. D. Bost, T. J. McDonald, and P. J. Morris, 2002, Aerobic biodegradation of hopanes and other biomarkers by crude oil-degrading enrichment cultures: Environmental Science \& Technology, v. 36, no. 21, p. 4585-4592, doi:10.1021/es025894x.

Frost, B. R., 1997, A Cretaceous Niger Delta petroleum system: Extended abstracts: AAPG/Associação Brasileira de Geólogos do Petróleo Hedberg Research Symposium, Petroleum Systems of the South Atlantic Margin, Rio de Janeiro, Brazil, November 16-19, 1997, 3 p.

Gelpi, E., H. Schneider, J. Mann, and J. Oró, 1970, Hydrocarbons of geochemical significance in microscopic algae: Phytochemistry, v. 9, no. 3, p. 603-612, doi:10.1016 /S0031-9422(00)85700-3.

Goodwin, N. S., P. J. D. Park, and A. P. Rawlinson, 1983, Crude oil biodegradation under simulated and natural conditions, in M. Bjorøy, C. Albrecht, and C. Cornford, eds., Advances in organic geochemistry: New York, John Wiley \& Sons, p. 650-658.

Haack, R. C., P. Sundararaman, J. O. Diedjomahor, H. Xiao, N. J. Gant, E. D. May, and K. Kelsch, 2000, Niger Delta petroleum systems, Nigeria, in M. R. Mello and B. J. Katz, eds., Petroleum systems of the South Atlantic margins: AAPG Memoir 73, p. 213-232.

He, M., J. M. Moldowan, A. Nemchenko-Rovenskaya, and K. E. Peters, 2012, Oil families and their inferred source rocks in the Barents Sea and northern Timan-Pechora Basin, Russia: AAPG Bulletin, v. 96, no. 6, p. 1121--1146, doi:10.1306/10181111043.

Head, I. M., D. M. Jones, and S. R. Larter, 2003, Biological activity in the deep subsurface and the origin of heavy oil: Nature, v. 426 , no. 6964 , p. 344-352, doi:10.1038 /nature02134.

Hoffmann, C. F., A. S. Mackenzie, C. A. Lewis, J. R. Maxwell, L. L. Oudin, B. Durand, and M. Vandenbroucke, 1984, A biological marker study of coals, shales and oils from the Mahakam Delta, Kalimantan, Indonesia: Chemical Geology, v. 42, no. 1-4, p. 1-23, doi:10.1016/00092541(84)90002-0.

Huang, W.-Y., and W. G. Meinschein, 1979, Sterols as ecological indicators: Geochimica et Cosmochimica Acta, v. 43 , no. 5, p. 739-745, doi:10.1016/0016-7037(79) 90257-6.

Hunt, J. M., A. Y. Huc, and J. K. Whelan, 1980, Generation of light hydrocarbons in sedimentary rocks: Nature, v. 288, no. 5792, p. 688-690, doi:10.1038/288688a0.

Killops, S. D., R. H. Funnell, R. P. Suggate, R. Sykes, K. E. Peters, C. Walters, A. D. Woolhouse, R. J. Weston, and J.-P. Boudou, 1998, Predicting generation and expulsion of paraffinic oil from vitrinite-rich coals: Organic Geochemistry, v. 29, no. 1-3, p. 1-21, doi:10.1016 /S0146-6380(98)00087-4. 
Kulke, H., 1995, Nigeria, in H. Kulke, ed., Regional petroleum geology of the world. Part II: Africa, America, Australia and Antarctica: Berlin, Gebruder Borntraeger, p. 143-172.

Lambert-Aikhionbare, D. O., and A. C. Ibe, 1984, Petroleum source-bed evaluation of the Tertiary Niger delta: AAPG Bulletin, v. 68, no. 3, p. 387-389.

Lehne, E., and V. Dieckmann, 2010, Improved understanding of mixed oil in Nigeria based on pyrolysis of asphaltenes: Organic Geochemistry, v. 41, no. 7, p. 661-674, doi:10.1016/j.orggeochem.2010.04.003.

Lehner, P., and P. A. C. De Ruiter, 1977, Structural history of Atlantic margin of Africa: AAPG Bulletin, v. 61, no. 7, p. 961-981, doi:10.1306/C1EA43B0-16C9-11D78645000102C1865D.

Li, J., P. Paul, and M. Cui, 2000, Methyl diamantane index (MDI) as a maturity parameter for Lower Palaeozoic carbonate rocks at high maturity and overmaturity: Organic Geochemistry, v. 31, no. 4, p. 267-272, doi: 10.1016/S0146-6380(00)00016-4.

Li, Y., Y. Xiong, Y. Chen, and Y. Tang, 2014, The effect of evaporation on the concentration and distribution of diamondoids in oils: Organic Geochemistry, vol. 69, p. 88-97, doi:10.1016/j.orggeochem.2014.02.007.

Lijmbach, G. W. M., 1975, On the origin of petroleum: Proceedings of the 9th World Petroleum Congress, Tokyo, Japan, May 11-16, 1975, v. 2, p. 357-369.

Liu, J.-P., X.-h. Pan, J. Ma, Z.-j. Tian, Y.-j. Chen, and L.-k. Wan, 2008, Petroleum geology and resources in West Africa: An overview: Petroleum Exploration and Development, v. 35, no. 3, p. 378-384, doi:10.1016 /S1876-3804(08)60086-5.

Mackenzie, A. S., 1984, Applications of biological markers in petroleum geochemistry, in J. Brooks and D. Welte, eds., Advances in petroleum geochemistry, London, Academic Press, v. 1, p. 115-214, doi:10.1016/B978-0-12-0320011.50008-0.

Mango, F. D., 1997, The light hydrocarbons in petroleum: A critical review: Organic Geochemistry, v. 26, no. 7-8, p. 417-440, doi:10.1016/S0146-6380(97)00031-4.

McCaffrey, M. A., J. M. Moldowan, P. A. Lipton, R. E. Summons, K. E. Peters, A. Jeganathan, and D. S. Watt, 1994, Paleoenvironment implication of novel $\mathrm{C}_{30}$ sterane in Precambrian to Cenozoic age petroleum and bitumen: Geochimica et Cosmochimica Acta, vol. 58, p. 529-532, doi:10.1016/0016-7037(94)90481-2.

McHargue, T. R., 1990, Stratigraphic development of protoSouth Atlantic rifting in Cabinda, Angola - A petroliferous lake basin, in B. J. Katz, ed., Lacustrine basin exploration case studies and modern analogs: AAPG Memoir 50, p. 307-326.

Moldowan, J. M., J. Dahl, D. Zinniker, and S. M. Barbanti, 2015, Underutilized advanced geochemical technologies for oil and gas exploration and production-1. The diamondoids: Journal of Petroleum Science and Engineering, v. 126, p. 87-96, doi:10.1016/j.petrol.2014.11.010.

Moldowan, J. M., W. K. Seifert, and E. J. Gallegos, 1985, Relationship between petroleum composition and depositional environment of petroleum source rocks: AAPG Bulletin, v. 69 , no. 8 , p. 1255-1268.
Moldowan, J. M., P. Sundararaman, and M. Schoell, 1986, Sensitivity of biomarker properties to depositional environment and/or source input in the Lower Toarcian of SW-Germany: Organic Geochemistry, v. 10, p. 915-926, doi:10.1016/S0146-6380(86)80029-8.

Nasir, S., and T. Fazeelat, 2013, Diamondoid hydrocarbons as maturity indicators for condensates from southern Indus Basin, Pakistan: Journal of Chemistry, v. 2013, 636845, 10 p., doi:10.1155/2013/636845.

Nwachukwu, J. I., and P. I. Chukwura, 1986, Organic matter of Agbada Formation, Niger Delta, Nigeria: AAPG Bulletin, v. 70, no. 1, p. 48-55, doi:10.1306/948856241704-11d7-8645000102c1865d.

Obaje, N. G., 2009, Geology and mineral resources of Nigeria: London, Springer, Lecture Notes in Earth Science, v. 120, 221 p., doi:10.1007/978-3-540-92685-6.

Obermajer, M., M. G. Fowler, F. Goodarzi, and L. R. Snowdon, 1996, Assessing thermal maturity of Palaeozoic rocks from reflectance of chitinozoa as constrained by geochemical indicators: An example from southern Ontario, Canada: Marine and Petroleum Geology, v. 13, no. 8, p. 907-919, doi:10.1016/S0264-8172(96)00036-0.

Peters, K. E., and J. Moldowan, 1991, Effects of source, thermal maturity, and biodegradation on the distribution and isomerization of homohopanes in petroleum: Organic Geochemistry, v. 17, no. 1, p. 47-61, doi:10.1016 /0146-6380(91)90039-M.

Peters, K. E., J. W. Snedden, A. Sulaeman, J. F. Sarg, and R. J. Enrico, 2000, A new geochemical-stratigraphic model for the Mahakam Delta and Makassar Slope, Kalimantan, Indonesia: AAPG Bulletin, v. 84, no. 1, p. 12-44.

Radke, M., D. H. Welte, and H. Willsch, 1986, Maturity parameters based on aromatic hydrocarbons: Influence of the organic matter type: Organic Geochemistry, v. 10, p. 51-64, doi:10.1016/0146-6380(86)90008-2.

Reijers, T., 2011, Stratigraphy and sedimentology of the Niger Delta: Geologos, v. 17, no. 3, p. 133-162, doi:10.2478 /v10118-011-0008-3.

Samuel, O. J., C. Cornford, M. Jones, O. A. Adekeye, and S. O. Akande, 2009, Improved understanding of the petroleum systems of the Niger Delta Basin, Nigeria: Organic Geochemistry, v. 40, no. 4, p. 461-483, doi: 10.1016/j.orggeochem.2009.01.009.

Samuel, O. J., D. M. Jones, and C. Cornford, 2007, Intradelta versus sub-delta sourcing of petroleum - A global review: AAPG Search and Discovery article 40243, accessed June 15, 2015, http://www.searchanddiscovery .com/pdfz/documents/2007/07048samuel/images/samuel .pdf.html.

Scalan, E. S., and J. E. Smith, 1970, An improved measure of the odd-even predominance in the normal alkanes of sediment extracts and petroleum: Geochimica et Cosmochimica Acta, v. 34, no. 5, p. 611-620, doi:10.1016 /0016-7037(70)90019-0.

Schiefelbein, C. F., J. E. Zumberge, N. C. Cameron, and S. W. Brown, 1999, Petroleum systems in the South Atlantic margins, in N. R. Cameron, R. H. Bate, and V. S. Clure, eds., The oil and gas habitats of the South Atlantic: Geological 
Society, London, Special Publications 1999, v. 153, p. 169-179, doi:10.1144/GSL.SP.1999.153.01.11.

Schulz, L. K., A. Wilhelms, E. Rein, and A. S. Steen, 2001, Applications of diamondoids to distinguish source rock facies: Organic Geochemistry, v. 32, no. 3, p. 365-375, doi:10.1016/S0146-6380(01)00003-1.

Seifert, W. K., and J. M. Moldowan, 1980, The effect of thermal stress on source-rock quality as measured by hopane stereochemistry: Physics and Chemistry of the Earth, v. 12, p. 229-237, doi:10.1016/0079-1946(79)90107-1.

Seifert, W. K., and J. M. Moldowan, 1986, Use of biological markers in petroleum exploration, in R. B. Johns, ed., Biological markers in the sedimentary record: New York, Elsevier, p. 261-290.

Shanmugam, G., 1985, Significance of coniferous rain forests and related organic matter in generating commercial quantities of oil, Gippsland basin, Australia: AAPG Bulletin, v. 69, no. 8, p. 1241-1254.

Short, K. C., and A. J. Stauble, 1967, Outline of geology of Niger Delta: AAPG Bulletin, v. 51, no. 5, p. 761-779.

Sonibare, O., H. Alimi, D. Jarvie, and O. A. Ehinola, 2008, Origin and occurrence of crude oil in the Niger delta, Nigeria: Journal of Petroleum Science and Engineering, v. 61 , no. $2-4$, p. 99-107, doi:10.1016/j.petrol.2008 .05 .002 .

Stacher, P., 1995, Present understanding of the Niger Delta hydrocarbon habitat, in M. N. Oti and G. Postma, eds., Geology of deltas: Rotterdam, the Netherlands, August Aimé Balkema, p. 257-267.

Teisserenc, P., and J. Villemin, 1990, Sedimentary basin of Gabon - Geology and oil systems, in J. D. Edwards and P. A. Santogrossi, eds., Divergent/passive margin basins: AAPG Memoir 48, p. 117-199.

Ten Haven, H. L., 1996, Applications and limitations of Mango's light hydrocarbon parameters in petroleum correlation studies: Organic Geochemistry, v. 24, no. 10-11, p. 957-976, doi:10.1016/S0146-6380(96)00091-5.

ten Haven, H. L., J. W. de Leeuw, J. Rullkötter, and J. S. Sinninghe-Damsté, 1987, Restricted utility of the pristane/phytane ratio as a palaeoenvironmental indicator: Nature, v. 330, no. 6149, p. 641-643, doi: 10.1038/33064la0.

Thomas, D., 1995, Exploration gaps exist in Nigeria's prolific delta: Oil \& Gas Journal, v. 93, p. 66-71.

Thompson, K. F. M., 1983, Classification and thermal history of petroleum based on light hydrocarbons: Geochimica et Cosmochimica Acta, v. 47, no. 2, p. 303-316, doi: 10.1016/0016-7037(83)90143-6.

Thompson, K. F. M., 1987, Fractionated aromatic petroleums and the generation of gas-condensates: Organic Geochemistry, v. 11, no. 6, p. 573-590, doi:10.1016/01466380(87)90011-8.

Thompson, K. F. M., 1988, Gas-condensate migration and oil-fractionation in deltaic systems: Petroleum Geology, v. 5, p. 237-246, doi:10.1016/0264-8172(88)90004-9.

Tuttle, M. L. W., R. R. Charpentier, and M. E. Brownfield, 1999, The Niger Delta petroleum system: Niger Delta Province, Nigeria, Cameroon, and Equatorial Guinea, Africa: Chapter A: Tertiary Niger Delta (Akata-Agbada) petroleum system (no. 719201): US Geological Survey Open-File Report 99-509H, accessed January 15, 2014, http://pubs.usgs.gov/of/1999/ofr-99-0050/OF99-50H /OF99-50H.pdf.

Ukpabio, E. J., P. A. Comet, R. Sassen, and J. M. Brooks, 1994, Triterpenes in Nigerian oil: Organic Geochemistry, v. 22, no. 2, p. 323-329, doi:10.1016/01466380(94)90178-3.

van Aarssen, B. G. K., T. P. Bastow, R. Alexander, and R. I. Kagi, 1999, Distributions of methylated naphthalenes in crude oils: Indicators of maturity, biodegradation and mixing: Organic Geochemistry, v. 30, no. 10, p. 1213-1227, doi:10.1016/S0146-6380(99)00097-2.

Weber, K. J., and E. M. Daukoru, 1975, Petroleum geology of the Niger Delta: Proceedings of the 9th World Petroleum Congress, Tokyo, Japan, May 11-16, 1975, v. 2, p. 210-221.

Wei, Z., J. M. Moldowan, K. E. Peters, Y. Wang, and W. Xiang, 2007, The abundance and distribution of diamondoids in biodegraded oils from the San Joaquin Valley: Implications for biodegradation of diamondoids in petroleum reservoirs: Organic Geochemistry, v. 38, no. 11, p. 1910-1926, doi:10.1016/j.orggeochem 2007.07.009.

Wenger, L. M., C. L. Davis, and G. H. Isaksen, 2002, Multiple controls on petroleum biodegradation and impact on oil quality: SPE Reservoir Evaluation \& Engineering, v. 5, no. 5, p. 375-383, doi:10.2118/80168-PA.

Whiteman, A., 1982, Nigeria: Its petroleum geology, resources and potential: Dordrecht, the Netherlands, Springer, v. 1, 394 p., doi:10.1007/978-94-009-7361-9. 